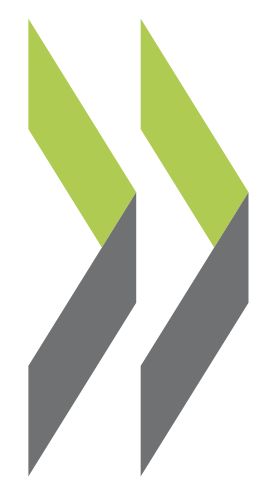

OECD Economics Department Working Papers No. 1433

Breaking the Shackles: Zombie Firms, Weak Banks and Depressed Restructuring in Europe

\section{Dan Andrews,}

\section{Filippos Petroulakis}


Organisation de Coopération et de Développement Économiques

Organisation for Economic Co-operation and Development

16-Nov-2017

ECONOMICS DEPARTMENT

English - Or. English

BREAKING THE SHACKLES: ZOMBIE FIRMS, WEAK BANKS AND DEPRESSED RESTRUCTURING IN EUROPE

ECONOMICS DEPARTMENT WORKING PAPERS No. 1433

By Dan Andrews and Filippos Petroulakis

OECD Working Papers should not be reported as representing the official views of the OECD or of its member countries. The opinions expressed and arguments employed are those of the author(s).

Authorised for publication by Christian Kastrop, Director, Policy Studies Branch, Economics Department.

All Economics Department Working Papers are available at www.oecd.org/eco/workingpapers

JT03423079

This document, as well as any data and map included herein, are without prejudice to the status of or sovereignty over any territory, to the delimitation of international frontiers and boundaries and to the name of any territory, city or area. 
OECD Working Papers should not be reported as representing the official views of the OECD or of its member countries. The opinions expressed and arguments employed are those of the author(s).

Working Papers describe preliminary results or research in progress by the author(s) and are published to stimulate discussion on a broad range of issues on which the OECD works.

Comments on Working Papers are welcomed, and may be sent to OECD Economics Department, 2 rue André-Pascal, 75775 Paris Cedex 16, France, or by e-mail to eco.contact@oecd.org.

All Economics Department Working Papers are available at www.oecd.org/eco/workingpapers.

This document and any map included herein are without prejudice to the status of or sovereignty over any territory, to the delimitation of international frontiers and boundaries and to the name of any territory, city or area.

The statistical data for Israel are supplied by and under the responsibility of the relevant Israeli authorities. The use of such data by the OECD is without prejudice to the status of the Golan Heights, East Jerusalem and Israeli settlements in the West Bank under the terms of international law.

\section{(C) OECD (2017)}

You can copy, download or print OECD content for your own use, and you can include excerpts from OECD publications, databases and multimedia products in your own documents, presentations, blogs, websites and teaching materials, provided that suitable acknowledgment of OECD as source and copyright owner is given. All requests for commercial use and translation rights should be submitted to rights@oecd.org 


\section{ABSTRACT/RÉSUMÉ}

\section{Breaking the Shackles: Zombie Firms, Weak Banks and Depressed Restructuring in Europe}

This paper explores the connection between "zombie" firms (firms that would typically exit in a competitive market) and bank health and the consequences for aggregate productivity in 11 European countries. Controlling for cyclical effects, the results show that zombie firms are more likely to be connected to weak banks, suggesting that the zombie firm problem in Europe may at least partly stem from bank forbearance. The increasing survival of zombie firms congests markets and constrains the growth of more productive firms, to the detriment of aggregate productivity growth. Our results suggest that around one-third of the impact of zombie congestion on capital misallocation could be directly attributed to bank health and additional analysis suggests that this may partly be due to reduced availability of credit to healthy firms. Finally, improvements in bank health are more likely to be associated with a reduction in the prevalence of zombie firms in countries where insolvency regimes do not unduly inhibit corporate restructuring. Thus, leveraging the important complementarities between bank strengthening efforts and insolvency regime reform would contribute to breaking the shackles on potential growth in Europe.

JEL codes: D24, G21, L25, O47.

Keywords: Zombie Firms; Factor Reallocation; Productivity; Credit Constraints.

$$
* * * * * * * * * * * * * * * * * * * *
$$

\section{Sociétés zombies, fragilité des banques et atonie des restructurations en Europe : libérer la croissance de ses entraves}

Dans cette étude, on analyse les liens entre les sociétés «zombies (ces sociétés non viables qui, normalement, sortiraient du marché dans un environnement soumis à la concurrence), la situation financière des banques et leurs conséquences pour la productivité globale dans onze pays européens. Une fois neutralisés les effets cycliques, les résultats montrent que ces sociétés zombies sont plus souvent liées à des banques fragiles, ce qui laisse penser que le problème qu'elles posent en Europe tient peut-être, en partie au moins, au laxisme du système bancaire. Leur survie croissante aboutit à la congestion des marchés et entrave la croissance d'entreprises plus productives, au détriment de gains dans la productivité globale. Les résultats de notre analyse indiquent que les effets de cette prolifération de sociétés non viables sur une mauvaise allocation du capital pourraient directement être imputés, pour un tiers environ, à l'état de santé des banques et, si l'on pousse l'analyse, qu'une disponibilité réduite de l'offre de crédit aux entreprises en bonne santé pourrait, en partie, en être la cause. Enfin, l'amélioration de la santé du système bancaire va plus souvent de pair avec une diminution du nombre de sociétés zombies dans les pays où le régime de faillite n'entrave pas inutilement la restructuration des entreprises. Aussi, la mise à profit des complémentarités entre les initiatives de consolidation des banques et la réforme des procédures de faillite concourrait à libérer la croissance potentielle de ses entraves.

Classification JEL: D24, G21, L25, O47.

Mots-clés: sociétés zombies ; redéploiement des facteurs ; productivité; difficultés d'accès au crédit. 


\section{TABLE OF CONTENTS}

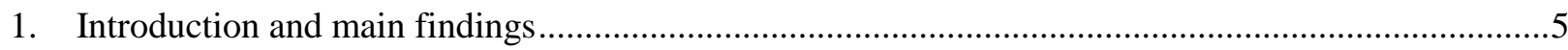

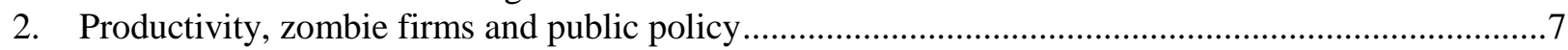

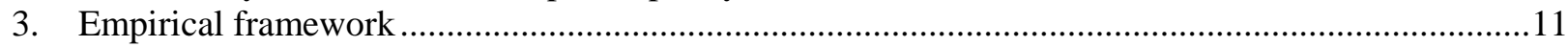

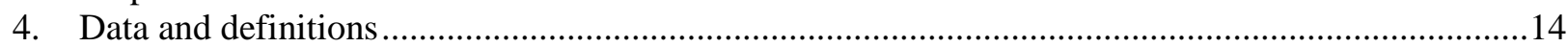

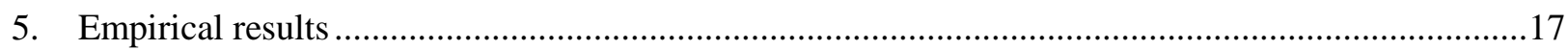

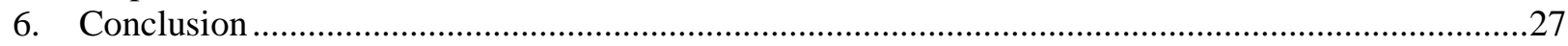

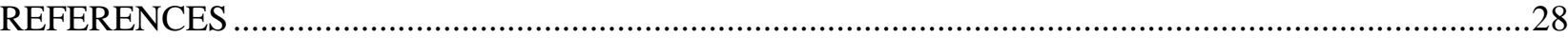

APPENDIX A: ADDITIONAL TABLES AND FIGURES …...............................................................

\section{Tables}

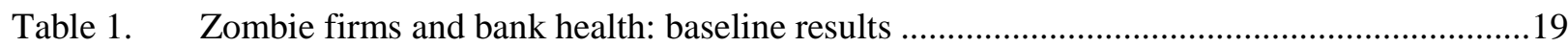

Table 2. Zombie firms and bank health: role of insolvency regimes ............................................21

Table 3. Capital reallocation, bank health and zombie congestion................................................24

Table 4. Credit availability for healthy firms and zombie congestion..............................................26

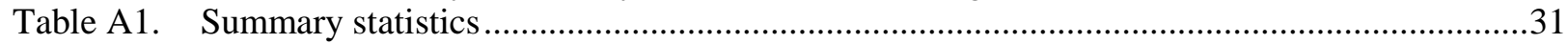

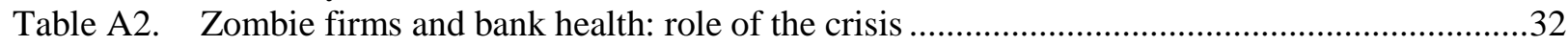

Table A3. Zombie firms and bank health: robustness tests ...............................................................33

Table A4. Zombie firms, bank health and insolvency regimes: robustness ….......................................34

Table A5. Capital reallocation and bank health: robustness tests ........................................................35

\section{Figures}

Figure 1. Decomposition of the growth rate of OECD potential output per capita ...............................

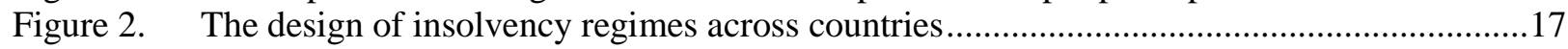

Figure 3. Zombie firms are connected to weak banks ................................................................18

Figure 4. Insolvency regimes shape the link between zombie firms and bank health .........................23

Figure 5. Zombie congestion and access to finance to healthy firms ................................................26

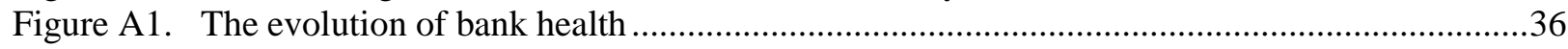

Figure A2. Zombie firms and weak banks: additional evidence ............................................................38

\section{Boxes}

Box 1. Measuring bank health .16 
ECO/WKP(2017)65

\title{
BREAKING THE SHACKLES: ZOMBIE FIRMS, WEAK BANKS AND DEPRESSED RESTRUCTURING IN EUROPE
}

\author{
By Dan Andrews and Filippos Petroulakis ${ }^{1}$
}

\section{Introduction and main findings}

1. The collapse in potential output growth over the past two decades brings into closer focus the structural barriers to productivity growth in Europe and the scope for policy to break these shackles. Firmlevel research is increasingly linking the aggregate productivity slowdown to the widening productivity dispersion across firms (Andrews et al. 2016), rising capital misallocation (Gopinath et al. 2017) and declining business dynamism (Decker et al. 2016). A related source of concern is that firms that would typically exit or be forced to restructure in a competitive market - i.e. "zombie firms" - are increasingly surviving, which may weigh on average productivity and crowd-out growth opportunities for more productive firms (Adalet McGowan et al. 2017b). In some countries, these problems may be symptomatic of impaired banking sectors. In this view, banks' reluctance or lack of incentives to deal with nonperforming loans (NPLs) and realize losses on their balance sheets that may arise from corporate insolvencies, may lead to "evergreening" of loans to zombie firms (i.e. bank forbearance). But almost everything we know about this issue is based on the Japanese experience of the 1990s (Caballero et al. 2008; Peek and Rosengren 2005) and cross-country research on the connection between zombie firms and weak banks is scarce.

2. Accordingly, this paper explores the connection between zombie firms and bank health and the resulting consequences for aggregate productivity growth. To this end, we assemble a cross-country micro dataset by linking ORBIS, the largest commercially available firm-level source of cross-country data, with bank-level information from Bankscope and microdata on firms' access to finance from the Survey on the Access to Finance for Enterprises (SAFE), run by the European Central Bank (ECB). We use principal components analysis to construct a multi-dimensional indicator of bank health, which takes into account tangible equity, net income, NPLs, return on assets, and measures of maturity mismatch and asset riskiness. Our final dataset covers 11 European countries, from 2001 to 2014. In turn, cross-country empirical analysis delivers four main policy findings.

3. First, after controlling for cyclical influences at the industry-country level, our baseline (withinindustry) estimates show that zombie firms have a higher likelihood of being connected to a weak bank. These results survive a battery of robustness tests. Assuming a causal relationship, our baseline estimates imply that weak banks (i.e. those one standard deviation below the mean of the bank health distribution) are between 1.2 and 2.2 percentage points more likely of being connected with a zombie firm compared to healthy banks (i.e. those one standard deviation above the mean of the bank health distribution). This translates into a $13 \%$ to $24 \%$ difference in zombie incidence between healthy and weak banks relative to the mean. These results are consistent with the idea that the zombie firm problem in Europe may at least partly stem from bank forbearance.

1. Corresponding authors are: Dan Andrews (Dan.Andrews@oecd.org) from the OECD Economics Department and Filippos Petroulakis (Filippos.Petroulakis@ecb.europa.eu) from the European Central Bank. The views expressed in this paper are those of the authors alone, and may not necessarily reflect those of the OECD or the European Central Bank. The authors would like to thank Giuseppe Nicoletti, Müge Adalet McGowan, Peter Gal, Valentine Millot and Jean-Marc Fournier from the OECD Economics Department and Bob Anderton, Isabel Vanksteenkiste, Beatrice Pierluigi, Agostino Consolo, Bjorn Fischer, Ralph Setzer, Manuela Storz and Livio Stracca from the European Central Bank. All errors are our own. 
4. We then explore the potential for the design of insolvency regimes to condition the link between zombie firms and bank health. Even when banks are healthy, an insolvency framework which creates impediments to corporate restructuring and reduces recovery rates for creditors may reduce the economic incentives for banks to commence the process of recovery, liquidation, or restructuring. Consistent with this idea, we exploit new OECD insolvency regime indicators (see Adalet McGowan et al, 2017a) to show that improvements in bank health are more likely to be associated with a reduction in the prevalence of zombie firms in countries where insolvency regimes do not unduly inhibit corporate restructuring. Put differently, the effectiveness of efforts to reduce NPLs will be limited if insolvency frameworks remain hostile to efficient restructuring. Taken together, these findings carry strong policy implications and imply that leveraging the important complementarities between efforts to restore bank health and insolvency regime reform will be important for breaking the shackles on potential growth in Europe.

5. Third, we explore the aggregate consequences of the zombie firm-weak bank connection through the channel of capital reallocation. We first replicate the key findings of Adalet McGowan et al. (2017b), and show that on average, more productive firms attract more capital (i.e. capital reallocation is productivity-enhancing) but the extent to which this is true diminishes as zombie congestion (i.e. the share of the industry capital stock sunk in zombie firms) rises. Consistent with the empirical link between zombie firms and bank health uncovered above, we then show that the capital reallocation process is less (more) productivity-enhancing in industries exposed to weaker (healthier) banks. For example, a one standard deviation increase in bank health would raise our preferred measure of the efficiency of capital reallocation (the difference in capital growth between firms one standard deviation above and below the sectoral mean of productivity) by 1.6 percentage points (from $6.6 \%$ to $8.2 \%$ ). Moreover, our results suggest that around one-third of the impact of zombie congestion on capital misallocation can be directly attributed to bank health. These findings are significant given that rising capital misallocation is emerging as a key explanation of the productivity slowdown in some countries (Gopinath et al. 2017).

6. Finally, we study the channels through which zombie congestion may adversely affect the growth opportunities of healthier and more productive firms. If zombie congestion crowds-out investment opportunities for healthier and more productive firms, then one would expect that this relationship is also reflected in access to credit. Using data from the Survey on the Access to Finance of Enterprises (SAFE) from the European Central Bank (ECB), we find a statistically significant negative relationship at the sectoral level between the share of capital sunk in zombie firms and credit availability for healthy firms. Intuitively, this could reflect direct crowd-out effects - i.e. banks cannot lend to healthy firms because their balance sheets are weakened due to their zombie exposure - or reduced borrowing capacity because zombie congestion has reduced industry profitability and thus the returns on potential projects of healthy firms. Assuming banks engage in sectoral diversification, we hypothesize that this is more likely to reflect the latter and less so direct crowd-out. These results should be interpreted with caution, however, given that the sample size is very small and the economic magnitude of the estimated coefficient is modest.

7. The paper is structured as follows. The following section illustrates the link between zombies and productivity weakness, and then reviews existing literature between zombie firms, weak banks, and insolvency regimes. Section 3 outlines the empirical strategy while Section 4 explains the data sources. Section 5 then provides new empirical evidence on four issues: $i$ ) the connection between zombie firms and weak banks; ii) how this link is conditioned by the design of insolvency regimes; iii) the aggregate consequences of the zombie firm-weak bank connection through the channel of capital reallocation; and $i v$ ) channels through which zombie congestion adversely affects growth, with a particular focus on healthy firms access to finance. Section 6 provides some concluding remarks. 


\section{Productivity, zombie firms and public policy}

\subsection{The exit margin as a source of productivity weakness}

8. Potential output growth has slowed by about one percentage point per annum across the EU since the late 1990s, which is entirely accounted for by a collapse in labor productivity growth. Digging deeper, this reflects a pre-crisis slowing in multi-factor productivity (MFP) growth (figure 1), and a more recent weakness in capital deepening (Ollivaud et al. 2016). This has raised questions about our societies' ability to make good on promises to current and future generations.

Figure 1. Decomposition of the growth rate of OECD potential output per capita

Contribution to potential output per capita growth

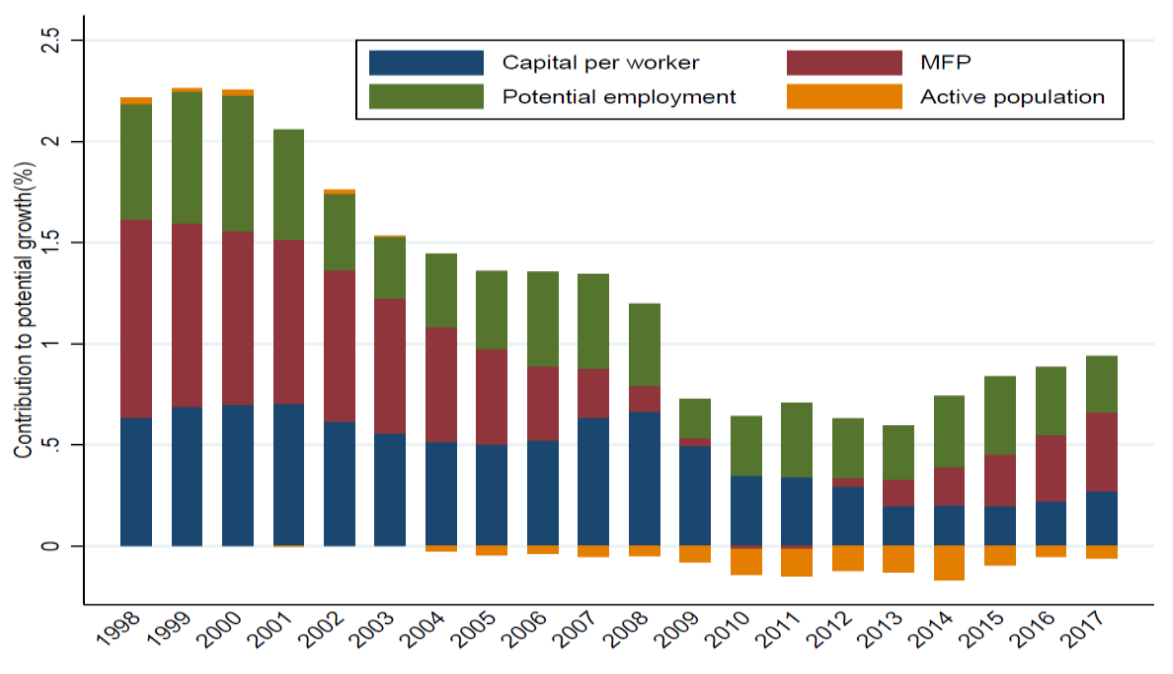

Source: OECD Economic Outlook Database.

9. A key lesson from recent research is that using aggregate data to understand the proximate drivers of productivity weakness only gets one so far. In fact, cross-country differences in aggregate productivity are increasingly being linked to the widespread asymmetry and heterogeneity in firm performance within sectors (Bartelsman et al. 2013, Hsieh \& Klenow 2009). The distribution of firm productivity is typically not clustered around the mean but is instead characterized by many below-average performers and a smaller number of star performers. Moreover, the degree of heterogeneity is striking: even within narrowly defined industries in the United States, firms at the 90th percentile of the MFP distribution are twice as productive as firms at the $10^{\text {th }}$ percentile (Syverson 2011).

10. This heterogeneity in firm performance is important as it creates scope for growth-enhancing resource reallocation. A theoretical literature dating back to Hopenhayn (1992) has posited that the exit of low productivity firms and the reallocation of their resources to more productive firms is key for aggregate MFP growth. Indeed, firm exit creates space for new varieties to emerge and new entrants productively recycle the assets of defunct firms across a range of activities. ${ }^{2}$ While this typically reflects the reallocation of tangible inputs, there is also scope for the post-exit diffusion of codified knowledge to new entrants via employee mobility and the sales of patents (Hoetker \& Agarwal 2007). More generally, these predictions

2. For the productive recycling of assets of exiting firms, see Australian Productivity Commission (2015) for the airline industry, Hiatt et al. (2009) for beverages, and Hoetker \& Agarwal (2007) for the disk drive industry. 
have been borne out in a host of empirical studies ${ }^{3}$, which document that within-industry resource reallocation is a significant contributor to - if not the predominant driver of - aggregate productivity growth. While the creative-destruction process in a well-functioning market economy compels poorly performing firms to improve their efficiency or exit the market, there are signs from recent firm-level studies that this process may be slowing down.

11. First, the level of productivity dispersion within industries has risen over time, implying a widening gap between more productive and less productive firms (Andrews et al. 2016). This finding of rising productivity dispersion is confirmed by a range of studies using alternate data sources (Decker et al. 2016, Berlingieri et al. 2017, Gamberoni et al. 2016) and it appears that it is not just driven by frontier firms pushing the boundary outward. Instead, it has been attributed to stagnating laggard firm productivity related to the declining ability or incentives of such firms to adopt best practices from the frontier (Andrews et al. 2016). This raises serious questions about what allows weak firms that do not adopt the latest technologies to remain in the market.

12. Second, the contribution of resource reallocation to aggregate productivity growth has declined over time. This is reflected in a declining responsiveness of firm growth (investment) to productivity over recent decades in Europe (Adalet McGowan et al. 2017b) and the United States (Decker et al., 2017), which implies that the propensity of high productivity firms to expand and low productivity firms to downsize (or exit) has fallen (Decker et al., 2017). Similarly, Gopinath et al. (forthcoming) document a rising dispersion of return to capital in the manufacturing sector in Spain, Italy, and Portugal in the run-up to the crisis, which they attribute to the misallocation of credit-driven capital inflows towards high net worth, but not necessarily productive, firms. Evidence of a decline in productivity-enhancing reallocation is particularly significant in light of rising productivity dispersion, which would ordinarily imply stronger incentives for productive firms to aggressively expand and drive out less productive firms.

13. Finally, rising productivity dispersion and declining productivity-enhancing reallocation have coincided with a decline in a variety of measures of business dynamism. A well-documented aspect of this development is that firm entry has declined in many countries (Criscuolo et al. 2014). Clearly, this does not augur well for productivity growth given that young firms possess a comparative advantage in commercializing radical innovations (Acemoglu et al. 2013) and place indirect pressure on incumbent firms to improve their productivity via technology adoption. But a less widely understood fact is that declining firm entry has also been accompanied by a rising survival probability of marginal firms that would typically exit in a competitive market (Andrews et al. 2016).

14. The prolonged survival of such firms not only weighs on average productivity but potentially crowds-out growth opportunities for more productive firms. Until recently, almost everything we knew about this issue was confined to Japan in the 1990s. In this regard, Caballero et al. (2008) argue that the survival of zombie firms congests markets and lowers industry profitability - by inflating wages relative to productivity and depressing market prices - which deters the expansion of healthier firms. Using firm-level data for the Japanese episode, Caballero et al (2008) infer whether a firm is a zombie by comparing its interest payments to prime lending rates. They confirm that in industries where a higher share of capital is sunk in zombie firms, healthy firms experience lower investment and employment growth, and that the productivity gap between non-zombie and zombie firms is higher, implying that new firms need to clear a wide productivity threshold in order to enter the market.

15. Outside of the Japanese episode, Adalet McGowan et al. (2017b) apply the same framework to a broad sample of OECD countries. After controlling for cyclical influences at the industry-country level, a higher share of industry capital sunk in zombie firms is found to crowd-out the growth - in terms of investment and employment - of healthy firms within an industry. Moreover, young firms are particularly

3. See Baily et al. (1992), Foster et al. (2006), Baldwin \& Gu (2006), Disney et al. (2003). 
affected. They find that up to one-quarter of the actual decline in aggregate business investment in Italy between 2008 and 2013 can be linked to the rise in zombie congestion. But the story does not end there since zombie congestion disproportionately crowds-out the growth of more productive firms, thus slowing aggregate MFP growth via less efficient capital reallocation. In Spain, for example, perhaps one-half of the decline in the efficiency of capital reallocation can be accounted for by the rise in zombie congestion.

\subsection{Zombie firms and weak banks}

16. Despite the renewed research interest in zombie firms and their aggregate consequences, the literature on the causes of the problem is slimmer. The seminal paper on the emergence of zombies in Japan is Peek and Rosengren (2005), who confirm the widely suspected phenomenon of "evergreening", whereby banks engage in zombie lending by continuing to finance weak or even insolvent firms ("unnatural selection"). This was attributed to perverse institutional incentives, such as the reluctance of banks to write-off loans, which increased the closer was the reported capital to regulatory requirements ("balance sheet cosmetics"). Cultural incentives also mattered: banks had an implicit duty to support troubled firms, and relationship-lending forces were particularly important. Overall, 14 to $36 \%$ of all firms were zombies at some point, according to Kwon et al (2015). ${ }^{4}$

17. These studies from Japan provide insights into the proximate causes of zombie congestion in Europe. The most obvious account would emphasize the damage to the banking sector incurred from the financial crisis, which undermined its ability to channel scarce credit to the most efficient uses. In this regard, Acharya et al (2017) provide some evidence that undercapitalised banks in Europe have directed loans to zombie firms in order to avoid incurring losses on their loan portfolios, which - instead of raising real activity - crowded-out the growth of non-zombie firms via zombie congestion. ${ }^{5}$ At the same time, recent evidence shows that bank stress hinders the deleveraging process of zombie firms in the euro periphery (Storz et al., 2017).

18. Against this, Schivardi et al (2017) study the universe of loans in Italy in 2003-2014, matched with the universe of firms. While their results confirm both zombie lending and negative effects on healthy firms, they claim that the aggregate effects on MFP and the growth of healthy firms are minimal. ${ }^{6}$ They also find no evidence that bank capitalizations affects credit supply to non-zombies. While this paper is clearly related to our own, it differs in two key respects. First, Schivardi et al (2017) focus on new lending. Under the stricter supervision landscape in Europe, however, new lending to zombies may only constitute a small part of the forbearance strategy of banks. Instead, indirect means of forbearance - i.e. beneficial

4. Subsequent work has shed further light on the nuances of the Japanese episode. Sakai et al. (2010) found that small firms that eventually defaulted performed worse and paid higher interest rates than surviving firms. This finding - which contradicts Peek and Rosengren - may reflect differences in sample composition, particularly the focus on listed firms only in the seminal study. Against this, Akiyoshi and Kobayashi (2010) directly test for the effect of bank distress on firm productivity and confirm the negative link. Nishimura et al (2005) find that firms with relatively high MFP exited, while firms with relatively low MFP stayed in the market, an indication of unnatural selection. Okada and Horioka (2008) argued that the selection mechanism was disruptive, with banks giving preference to high and low MFP firms, at the expense of medium MFP firms, who presumably could survive even with rationed credit.

5. Note that the study is conducted using data from the syndicated loan market only, and so misses lending to SMEs, as well as non-syndicated credit (bonds and loans). Moreover, it takes place in the context of a policy with likely favourable general equilibrium effects, which could have affected the outlook of the troubled firms from the point of view of the bank. As such, general equilibrium effects are missing from the analysis.

6. Note, however, that Schivardi et al (2017) find that a bank recapitalization of 4 billion euros in 2012 ( $0.25 \%$ of GDP), would lead to additional GDP growth of $0.2-0.35 \%$ annually for five years, which is arguably sizable. 
restructuring, maturity extension or conversion of the payment structure (i.e. from regular instalments to a lump-sum payment at maturity) - may be more prevalent. For this reason, we implicitly focus on forbearance strategies by considering indebtedness when constructing zombie firm indicators, and not only new lending. ${ }^{7}$ Second, Schivardi et al (2017) consider the bank-firm relationship, and therefore abstract from the possibility that lending is restricted because healthy firms lack the profitability required to get good credit, due to zombie congestion. By contrast, we employ a catch-all approach and thus consider all types of zombie-friendly behaviour.

\subsection{Zombie firms, bank health and insolvency regimes}

19. The fact that zombies appear after large shocks in some countries but not others suggests that there is a potentially important role for structural policies, particularly the extent to which insolvency regimes foster the timely initiation and resolution of insolvency proceedings. ${ }^{8}$ In this regard, new evidence assembled in Adalet McGowan et al (2017a) reveal significant differences across European countries in barriers to corporate restructuring and the personal costs associated with entrepreneurial failure implied by national insolvency regimes. Moreover, they demonstrate the potential for reforms to insolvency regimes to reduce the share of capital sunk in zombie firms. For example, reducing barriers to restructuring to best practices could reduce the zombie capital share by one-half and one-third in Italy and Greece, respectively. These gains are partly realized via the restructuring of weak firms, which in turn spurs the reallocation of capital to more productive firms (Adalet McGowan et al 2017a) and generates MFP gains within laggard firms via more efficient technological adoption (Adalet McGowan et al 2017c).

20. In a frictionless model, when a firm has trouble meeting its obligations to its debtor it will relinquish ownership of its collateral. If this is not sufficient to repay the value of the debt, it will enter into bankruptcy proceedings to determine the value of its assets, which are then sold-off to pay the remainder of the debt. The faster this process is completed, the sooner will the resources tied to the failing firm be able to be reallocated to more productive uses. In practice, there can be a number of frictions that emanate from the inability of the insolvency framework to address the existence of incomplete contracts, which can severely delay the orderly reallocation process. Smith \& Stromberg (2005) argue that the principal role of an orderly bankruptcy process is to mitigate bargaining frictions between the debtor and its creditor(s). By preventing a "rush to the exit" motive, a well-designed insolvency regime verifies the value of assets and liabilities, it maintains the value of assets during bargaining, and improves coordination among creditors, among others. ${ }^{9}$

21. In the context of zombie lending, poorly designed insolvency frameworks are likely to interact with evergreening motives. Recall that a bank will be willing to evergreen loans to a troubled firm (either by extending new loans or allowing non-payment of existing loans via restructuring of debt) because it does not want to write-off losses on its balance sheet and increase provisions. It will do so to the extent to which the amount recovered is not high enough to cover the increase in provisions or, even if expected recovery is complete, it is expected to be delayed to such an extent that the bank prefers to evergreen.

7. More specifically, Schivardi et al (2017) examine the classification of NPLs, they do not check to see whether weak banks have different strategies in how they treat problematic loans, which would be indicative evidence of forbearance.

8. For instance, we know little about why zombie firms emerged as a widespread phenomenon in 1990s Japan in contrast to other episodes. As Peek and Rosengren point out, this stands in contrast to the S\&L crisis, where banks quickly shrank their loan portfolios after the shock Indeed, that was the case even though loose lending standards from the previous decade were also a large part of the problem, and also in contrast to the last crisis, where debt overhang was a major concern several years after the shock.

9. Similar arguments are made by Marinc \& Vlahu (2012), who also underline the role of the bankruptcy regime in preventing hold-out problems. 
Thus, a poorly-designed insolvency framework ultimately implies a lower expected recovery value for the amounts owed to the bank and it follows that evergreening motives should be higher than under a more appropriate regime. This leads us to suspect that improvements in bank health are more likely to be associated with a reduction in the prevalence of zombie firms in countries where insolvency regimes do not unduly inhibit corporate restructuring.

\subsection{Four key issues for investigation}

22. Against this background, this paper addresses four key issues. First, it explores whether zombie firms are more likely to be connected to weak banks, in order to gauge the extent to which bank forbearance is a relevant policy concern. Second, it examines whether the aforementioned link between zombie firms and weak banks is conditioned by the design of insolvency regimes, with a view to highlight potential policy complementarities between financial sector and insolvency regime reform. Third, the paper explores consequences of the zombie firm-weak bank connection for aggregate productivity via the channel of capital reallocation. Finally, it contributes to the relatively scarce literature on the channels through which zombie firms affect growth, by examining whether zombie congestion crowds-out healthy firms' access to credit.

\section{Empirical framework}

\subsection{Zombie firms and weak banks}

23. Our first aim is to establish a robust connection between zombie firms and weak banks. To this end, we estimate the following baseline model for 11 countries $^{10}$, over the period 2003-2014:

$$
\text { zombie }_{i s c, t}=\alpha_{0}+\alpha_{1} \text { Bank Health }_{i s c, t-2}+X_{i s c, t-2} \Theta+\gamma_{s c, t}+\varepsilon_{i s c, t} .
$$

The dependent variable takes the value of 1 if the firm is classified as a zombie in a given year and 0 otherwise. Bank Health denotes the health of the bank associated with firm $i$ in sector $s$ in country $c$ and is increasing in health. ${ }^{11}$ We enter bank health in the model with a two-year lag $(t-2)$ in order to observe it at beginning of the time window used to define zombie firms (recall that firms are classified as zombies if they demonstrate persistent financial weakness for three consecutive years) but the results are also highly robust to using a three-year lag. ${ }^{12}$ The matrix $\mathrm{X}$ is composed of relevant firm-level controls, such as firm size, firm age and labour productivity. ${ }^{13}$ We use a rich fixed effect structure, denoted by $\gamma$. In our baseline specification we use a triple-interacted country-sector-year fixed effect, meaning that we control for the effects of time-varying shocks at the country-industry level, and we thus exploit firm-level variation within country-sector-year cells. Given our fixed effects structure, we are unable to use logit or probit models, and

10. These include: Austria, Denmark, Estonia, France, Germany, Greece, Latvia, Slovenia, Spain, Portugal, United Kingdom.

11. Although we mainly rely on the holistic bank health measure, we also briefly explore the role of different bank balance sheet variables.

12. We do this as we cannot know whether a troubled firm at time $t$ is allowed to survive by its bank because the bank judges it to have growth potential, or because the bank engages in zombie forbearance. As such, we need to observe the firm as being troubled for some time in order to be more confident classifying it as a zombie. At the same time, the timing relationship between bank health and the incentive to allow zombie firms to survive ("bad" forbearance), or simply engage in temporary forbearance for struggling firms with good growth prospects ("good" forbearance), is unclear.

13. We do this as we want to control for possible selection on size or age (which have been shown to be important) or for cases where productive firms are struggling and their banks forbear as they expect to see profits in the future (in which case forbearance is efficient), and isolate the effect of bank health. 
so we estimate all our models with OLS (via linear probability models). Since our working hypothesis is that healthier banks have less of an incentive to allow zombie firms to stay alive (or remain zombies, without restructuring their debt), we expect $\alpha_{1}<0$.

24. One implication of our high-dimensional fixed effects structure is that since we identify off deviations from within-group (i.e. country-industry-year) means, we potentially underestimate aggregate effects (which is indeed the case as we show in section 5). Intuitively, over the period we study, there was a worsening of bank health as a result of the financial crisis initially, and the sovereign debt crisis subsequently, for each country and sector. By imposing a triple-interacted fixed effect framework, we are effectively purging a lot of this variation. Thus, after establishing the robustness of our results to controlling for country-sector-year fixed effects, we also apply a less burdensome fixed effects structure, in order to produce a less conservative bound for the magnitude of our results. The latter involves controlling for time fixed effects (to absorb global shocks) and country-industry fixed effects to control for timeinvariant country-specific industry characteristics. We also report an upper bound effect that includes country-sector fixed effects but omits time effects.

\subsection{Zombie firms, bank health and insolvency regimes}

25. Next, we incorporate the insolvency framework indicators. We focus on four indicators, denoted by $\mathrm{INSOL}_{\mathrm{c}}$, as they vary only at the country level and pertain to a single point in time. ${ }^{14}$ Due to the lack of temporal variation, the level effect of the indicator variable is absorbed by the country fixed effect, and so we identify its effect from the interaction with bank health. We augment (1) as follows:

$$
\begin{aligned}
& \text { zombie }_{i s c, t}=\alpha_{0}+\alpha_{1} \text { Bank Health }_{i s c, t-2}+\alpha_{2} \text { Bank Health }_{i s c, t-2} \times I N S O L_{c} \\
& +X_{i s c, t-2} \Theta+\gamma_{s c, t}+\varepsilon_{i s c, t}
\end{aligned}
$$

26. The insolvency variables are defined as deviations from best practices, so a rising value of the indicator denotes a framework that is more likely to delay the initiation and resolution of insolvency proceedings. More specifically, our working assumption is that higher barriers to corporate restructuring, for example, will reduce the extent to which improvements in bank health translate into a reduction in zombie firm prevalence. Thus, our prediction is that $\alpha_{1}<0$, as before, and $\alpha_{2}>0$.

\subsection{Weak banks and capital misallocation}

27. To the extent that there is a connection between bank health and zombie status, then one would also expect there to be a connection between bank health and the efficiency of capital allocation; that is, capital should flow more readily to more productive firms in industries exposed to healthier banks. To test this hypothesis, we employ the same framework as Adalet McGowan et al. (2017b), augmenting a canonical firm dynamics model (Foster, Grim \& Haltiwanger 2016, Decker et al. 2016), which predicts that conditional on initial size, more productive firms should have higher growth potential and thus grow more quickly if reallocation is efficient. ${ }^{15}$ More specifically, the regression takes the following form:

$$
Y_{i s c, t}=\beta_{0}+\beta_{1} M F P_{i s c, t-1}+\beta_{2} M F P_{i s c, t-1} \times \text { BankHealth }_{s c, t-1}
$$

14. The indicators pertain to two separate years - 2010 and 2016 - and were collected in a single wave in 2016 and 2017. As our sample covers the period 2003-2014, we consider regressions with both years separately. Unfortunately, it is not possible to exploit time series variation in the indicator (see Adalet McGowan et al 2017a).

15. We prefer this approach to others used in the literature (e.g. Hsieh \& Klenow 2009) since firm growth is disciplined on MFP, which implies that we are isolating the component of capital reallocation that is truly productivity-enhancing. 


$$
+\beta_{3} M P_{i s c, t-1} \times Z_{\text {ZombieCapital }}^{s c, t-1}+X_{i s c, t-1} \Theta+\gamma_{s c, t}+\varepsilon_{i s c, t}
$$

where: $\mathrm{Y}$ is the growth in the capital stock for firm $i$, in sector $s$, country $c$, and time $t$, MFP denotes firmlevel multi-factor productivity measured as a deviation from the country-industry-year average to control for MFP differences across industries and countries, and Zombie Capital gives the share of industry capital sunk in zombie firms. We expect $\beta_{1}$ to be positive, consistent with the prediction that more productive firms should grow faster relative to their peers. A positive $\beta_{2}$ would indicate that in sectors exposed to healthy banks, this effect is magnified, and the efficiency of capital reallocation is strengthened. Put differently, sectors connected to more stressed banks should be characterized by less efficient capital reallocation. Finally, $\beta_{3}$ is expected to be negative, to the extent that a higher share of industry capital sunk in zombie firms crowds-out the growth of more productive firms (see Adalet McGowan et al. 2017b). The extent to which weak banks can account for the adverse effect of zombie congestion on capital reallocation can be quantified by comparing the estimated magnitude of $\beta_{3}$ from equation 3 with the estimated coefficient on MFPxZombie Capital term from a version of equation 3 that excludes the MFPxBankHealth term.

28. For the reallocation models, we focus on 7 countries from our sample which give us the broadest estimates of MFP at the firm level. These are Austria, France, Germany, Slovenia, Spain, Portugal, and the United Kingdom. See Adalet McGowan et al. (2017b) for more details.

\subsection{Zombie firms and credit crowd-out}

29. Finally, we explore the question of whether the survival of zombie firms crowds-out credit access to healthier firms, by combining data from ORBIS with SAFE, in a sample of 4 euro area countries (France, Germany, Italy and Spain). More specifically, we examine whether healthy firms operating in industries where a higher share of industry capital is sunk in zombie firms have more difficulty obtaining bank credit, than similar firms in sectors where zombie congestion is lower. The sample chosen is representative and we utilize the rolling panel component of the survey, which contains firm-level balance sheet information. The period covered is from 2009 to 2013.

30. The model is as follows:

$$
\text { CreditAvailability }_{i s c, t}=\delta_{0}+\delta_{1} \text { ZombieCapital }_{s c, t-1}+X_{i s c, t-1} \Theta+\gamma_{c, t}+\varepsilon_{i s c, t}
$$

where: Credit Availability is increasing in the extent to which bank loan (or credit line) availability for firms has improved over time (see section 4.2.4). The remaining variables are defined above. Contrary to the other models, the bulk of the variation in the zombie capital share is at the sectoral level, since zombie shares are highly persistent over time (85\% autocorrelation). As such, if we add sectoral effects, there is little variation left. Instead, we use country-year fixed effects - which controls for time-varying countryspecific shocks - and thus our variation comes from sectoral differences within each country in a specific year. In other words, we purge the industry zombie shares in each country of the country average in a given year and then exploit sectoral variation, based on 61 sectors (between NACE Rev 2. 10-82, excluding 6466 - i.e. financials). 


\section{ECO/WKP(2017)65}

\section{Data and definitions}

\subsection{Micro data sources}

31. Our firm-level data come from ORBIS - compiled by Bureau Van Dijk - the largest crosscountry panel database on the balance sheet and output data for firms. We adopt the same data cleaning and harmonisation procedures as Adalet McGowan et al. (2017b), who closely follow the suggestions of Gal (2013), Kalemli-Ozcan et al (2015) and Andrews et al (2016). The data is cleaned in a common manner across all countries, harmonizing balance sheets in terms of consolidation level and time horizon (calendar year). Firm-level nominal variables are deflated using 2-digit industry deflators from the OECD STAN database (as firm-level prices are not available, all productivity measures are revenue-based) and prices are expressed in industry purchasing power parities. We use the methods identified in Gal (2013) to construct capital stock and productivity variables (see below). ${ }^{16}$

32. Bank balance sheet data is sourced from Bankscope, which contains data for over 30,000 banks as far back as 2001. We match ORBIS and Bankscope based on the banker variable in ORBIS, and we follow the literature and assume that the stated banker relationship also implies a borrowing relationship. There is ample evidence in the recent literature (Kalemli-Ozcan et al. 2015, Chodorow-Reich 2014) that lending relationships are highly sticky. Consistent with other papers, we are able to match a very large fraction of our firms to their main bank (Kalemli-Ozcan et al. 2015, Storz et al. 2017), with match rates exceeding $90 \%$ in most countries. For cases where the firm mentions more than one bank, we assume that the first bank mentioned is the main one. Summary statistics are given in Table A1. Finally, we exploit restricted microdata on firms' access to finance from the Survey on the Access to Finance for Enterprises (SAFE), run by the European Central Bank (ECB).

\subsection{Key variable definitions}

\subsubsection{Productivity}

33. For productivity, we use two different methods, depending on the application, with a goal of striking a balance between maximizing our sample, and using a robust estimate. As a control variable in the zombie firm regression analysis, we simply use gross output per employee, deflated using the 2-digit OECD STAN industry deflators mentioned above, which we denote as labour productivity (LPR). While this allows us to maximise data coverage, it should be noted that Bartelsman et al. (2013) find that LPR captures systematic variations in in value-added based labour productivity. For the reallocation regressions, we follow Adalet McGowan et al. (2017b), and use a productivity measure based on a Solow residual (MFPR).

\subsubsection{Zombie firms}

34. We employ two different definitions of zombie firms, each with the view of maximizing our sample, but our regression estimates are insensitive to the choice of measure. In each case, we only consider firms aged ten years or more, as start-ups are in general not expected to be profitable. First, we define as zombies - following Adalet McGowan et al. (2017b) - firms that register an interest coverage ratio (the ratio of profit to interest payments) below 1 for three years in a row. This measure intends to capture firms that are not profitable enough to cover debt payments - and thus on the margin of exit in a competitive market. We presume that these firms are potentially benefiting from creditor forbearance.

16. See Gal (2013) and Andrews et al (2016) for more details. 
35. One drawback of the interest coverage (IC) measure is that it requires data on interest payments, which are often sparsely reported in the countries for which we can successfully match firms to banks. As a complementary measure, we thus follow Storz et al (2017) and classify the firm as a zombie if it has: $i$ ) low debt service capacity for three years in a row ${ }^{17}$; and ii) either negative return on assets or negative investment for three years in a row. Again, the logic is that firms that have chronically low debt service capacity, negative returns on assets or negative investment are likely to be on the brink of exit, unless their creditors allow them to remain operational. This measure, which we call NRI, is highly correlated with the IC measure (correlation around 0.7), and allows for a larger sample of firms from all countries, plus the addition of Denmark and Estonia (where interest rate data are scarcely reported). Accordingly, we adopt this NRI definition when our dependent variable is a binary indicator of zombie firm status in order to maximise sample coverage, but are careful to show that our results are also robust to using the IC measure. In sections 5.3 and 5.4, however, where we focus on the zombie capital share and country coverage in more restricted, we employ the IC measure in order to ensure consistency and comparability with Adalet McGowan et al (2017b), whose baseline model we adopt.

\subsubsection{Bank Health}

36. Since the aim is to link bank health as a whole to zombie firms and capital reallocation, and not to characterize the relevant drivers of a bank balance sheet in detail, we rely on a holistic measure of bank health. Accordingly, we construct a bank health index by Principal Components Analysis of the following measures: capital (TCE), NPLs, return on average assets (ROAA), Retail Funding, Z-Score, Net Income, and Net Interest Income. ${ }^{18}$ Retail Funding is given by the ratio of retail deposits and total assets, and is intended to measure the extent to which the bank relies on sticky retail deposits, as opposed to more volatile wholesale funding (such as money market funds, whose dry-up was a key driver of bank stress in the euro crisis). The Z-Score is given by the sum of ROAA and TCE, divided by the standard deviation of ROAA, and captures the riskiness of bank assets. Of course, there are a number of challenges in measuring bank health (see Box 1), which should be kept in mind.

37. Figure A1 of Appendix A shows the evolution of the average value of the bank health indicator for the whole sample and for each country in our sample separately. Overall the indicator for each country aligns well with the evolution of the crisis. The earlier parts of the crisis saw sharp declines in the health of Baltic banks followed by a relatively swift recovery, whereas the hit came later for Greece (the sharpest as expected), as well as Portugal, Spain, and Slovenia. Austria, Denmark, France, Germany and the United Kingdom exhibit much smaller declines in bank health, but typically do not recover to reach pre-crisis levels of health (partly due to low profitability).

17. Here, we set the limit for low debt service capacity as a ratio of EBIT to financial debt (sum of loans and long-term debt) below $20 \%$.

18. Principal Components Analysis has become fairly standard in economics, for applications where the precise nature and number of the relevant variables are unknown and the precise magnitude of each component variable not important (see Bernanke et al. 2005). Storz et al. (2017) take a similar approach. 


\section{Box 2. Measuring bank health}

Before proceeding, it is important to note that the ex-ante relationship between bank balance sheet variables and bank health, and by extension lending, is unclear. ${ }^{1}$ All things equal, a higher level of regulatory capital is considered a sign of a healthy balance sheet, but it could also be the result of low risk-taking, and little lending activity. At the same time, banks possessing high quality, high return assets, which generate a steady flow of income with limited risk, may afford to have relatively lower levels of capital adequacy. As such, capital may be a misleading metric of bank health. Risk-weighted (or regulatory) capital could be a potentially better measure but data availability issues force us to use Tangible Common Equity (TCE) as our measure of bank capital, which is typically the most stringent of all regulatory definitions and is not adjusted for risk. ${ }^{2}$ The same concerns hold for alternative indicators of bank health, over and above capital, as they are likely to measure different vulnerabilities. For instance, a high return on average assets (ROAA) and Net Interest Income indicate that a bank can withstand shocks by drawing down cash buffers, while low level of maturity mismatch implies that a bank may be less vulnerable to funding shock. Finally, we cannot observe exactly what determines bank health from the perspective of internal bank management. ${ }^{3}$

1. Strictly speaking, bank balance sheets refer to asset, liabilities, and equity capital. Here, we use the term to refer also to variables typically belonging to the bank's profit and loss (P\&L) statement, such as net income or return on assets.

2. TCE is the owner equity after removing preferred stock, goodwill, and intangible assets (the latter two generally refer to difficult to value and highly illiquid assets, such as trademarks). As such, it is typically thought of as the loss-absorbing capacity of the owners of the bank.

3. For example, the health of the bank as judged by its internal risk management framework will determine whether the managers deem the bank to be sound, and hence influence the forbearance strategy

\subsubsection{Access to finance for healthy firms}

38. To measure healthy firms' access to finance, we use a restricted microdata version of the Survey on the Access to Finance for Enterprises (SAFE), designed and run by the ECB to provide insight into the firms' perception of credit availability. The relevant question the survey asks firms is whether, compared to the previous six months, it is more difficult to obtain different types of bank credit; we focus on loans or credit lines. In each wave, we rescale the response variable as follows: -1 indicates that access to bank loan availability has worsened over the last six months; 0 indicates no change; and 1 indicates an improvement. We cumulate the access to bank credit variable across time for the duration of the presence of the firm in the sample to implicitly create an index of credit availability across time. For instance, if access improves for both semesters of 2012 and 2013, then the value for 2013 will be $4 .{ }^{19}$

39. We also use a composite financing gap indicator (see Ferrando et al., 2013) to take into account credit demand (and not just supply), which makes use of the self-reported change in financing needs for the firm (increased, decreased, or unchanged). The (rescaled) composite indicator takes a value of -1 for increased needs and deteriorating availability, -0.5 for either increased needs or deteriorating availability (but not both), and so forth. Again, responses are cumulated across time. ${ }^{20}$

\subsubsection{Insolvency Framework}

40. To test the effect of the insolvency framework on the relationship between bank health and zombie firms, we make use of a novel set of indicators developed by the OECD (see Adalet McGowan et

19. When we cumulate the semester-level data, we truncate the value to $+/-3$, as less than $1 \%$ of observations are outside this set. Results are very similar if instead we use the semester-level variables.

20. In detail for the other values: 0 for unchanged situation (increased need and improved availability, decreased need and deteriorated availability, or both unchanged); 0.5 for one-sided decreasing financing gap (decreased needs or improved availability, but not both); and 1 for two-sided decrease in financing gap (decreased needs and improved availability). 
al. (2017a). The set covers 13 different distinct features of the insolvency framework which - based on international best practice and existing research - may carry adverse consequences for productivity growth by delaying the initiation of and increasing the length of insolvency proceedings. We focus our attention on three composite indices - the aggregate index (insol13 - an unweighted average of the 13 components) plus two sub-indices: barriers to corporate restructuring and the lack of preventative and streamlining measures.

41. According to these metrics, cross-country differences in the design of insolvency regimes are significant. For example, the United Kingdom's low value on the aggregate composite indicators in Figure 2 reflects the fact that the personal costs associated with entrepreneurial failure and barriers to restructuring are low, while there is also a number of provisions to aid prevention and streamlining. In Estonia, however, the reverse is true and our working hypothesis is that this is likely to result in an insolvency regime which delays the timely restructuring of weak firms and thus slows down the reallocation of scarce resources to their most productive use. ${ }^{21}$

Figure 2. The design of insolvency regimes across countries, 2016

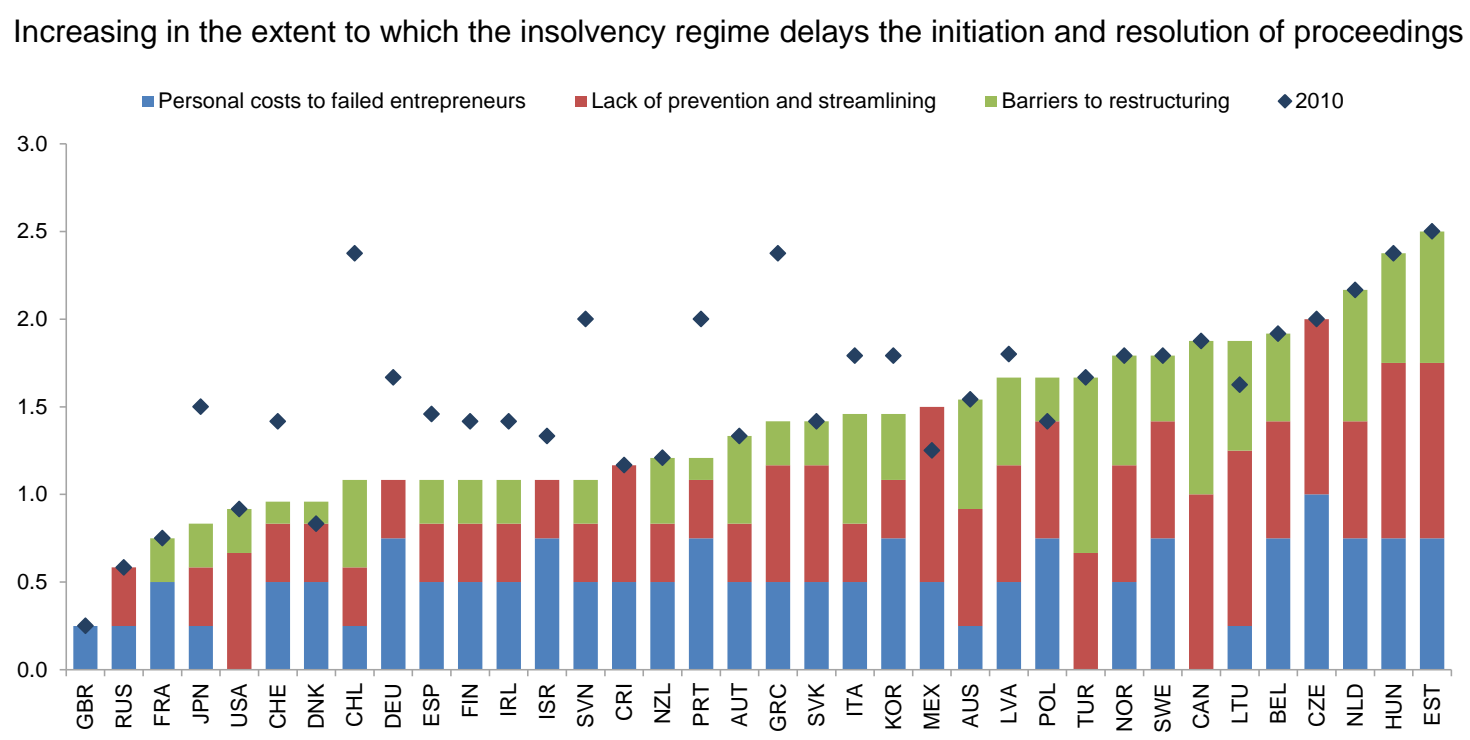

Note: The stacked bars correspond to three subcomponents of the insolvency indicator in 2016. The diamond corresponds to the value of the aggregate insolvency indicator based on these three subcomponents in 2010 . Only countries for which data are available for the three sub-components in 2016 are included.

Source: Calculations based on the OECD questionnaire on insolvency regimes. See Adalet McGowan et al. (2017a).

\section{Empirical results}

\subsection{Are zombie firms connected to weak banks?}

42. Figure 3 presents graphical evidence of the relationship between bank health and zombie firms. The graph shows the share of firms at the country-industry- year level associated with each bank that are defined as zombies (y variable), plotted against the two-year lags of the bank health composite index (x

21. As discussed in Adalet McGowan et al. (2017a), an inability of creditors to initiate restructuring, a lack of priority given to new financing over unsecured creditors and an indefinite stay on assets translates into significant barriers to corporate restructuring in Estonia. Similarly, a lack of early warning mechanisms, pre-insolvency regimes and special insolvency procedures for Small and Medium-Sized Enterprises (SMEs) imply that prevention and streamlining is weak in Estonia. 
variable). ${ }^{22}$ The red line is a linear regression fit of $\mathrm{y}$ on $\mathrm{x}$, purged of country-industry-year fixed effects to control for cyclical shocks at the country-industry level. For ease of observation, we split the sample of the $\mathrm{x}$ variable into 50 bins of equal size, and each point in the scatter plot gives the sample mean of $\mathrm{y}$ for each bin (after controlling for country-industry-year fixed effects). A strong negative relationship emerges between bank health and the zombie firm share, which we interpret as evidence that zombie firms are more likely to be connected to weak banks.

Figure 3. Zombie firms are connected to weak banks

Average zombie firm share for each bin of bank health

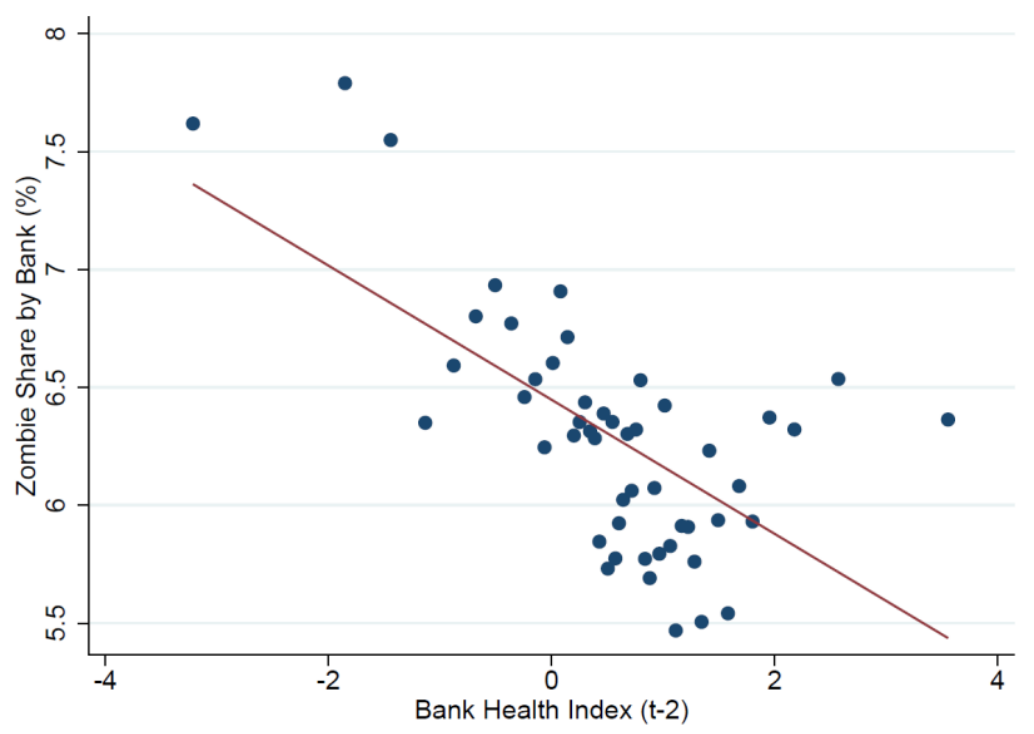

Note: The figure uses the binscatter command in Stata to shows the average zombie firm share (based on the NRI definition; see Section 4.2.2) for each bin of bank health, purged of country-industry-fixed effects. The relationship is statistically significant at the $1 \%$ level and is based on over 1.5 million firm-bank observations for 11 European countries over the period $2001-2014$.

43. Table 1 shows the results from our baseline model for zombies and banks (equation 1). Panel A shows the results from regressions with country-industry and year fixed effects, which remove time invariant country-industry effects, and also time-varying global shocks. The model in column 1 includes only bank capital and NPLs, to focus on the asset side. Both are highly significant and have the expected signs. Columns 2 and 3 progressively include more balance sheet variables, to account for the role of income, asset riskiness, and the risk coming from the liability side in the form of maturity mismatch. While the coefficients always have the expected signs, they are not always significant, illustrating the multicollinearity problem mentioned previously. As such, column 4 shows results from a model containing only the composite index, which is an increasing function of bank health. The estimated coefficient is negative, as expected, and statistically significant at the $1 \%$ level.

44. Panel B shows results from the more restrictive model that contains country-industry-year fixed effects, so variation comes from differences across firms operating in the same country-industry-year cell. Results are similar for most variables. Although coefficients are for the most part smaller in absolute value,

22. Figure A2 in the appendix shows the corresponding charts for the (seven) individual constituent components of the bank health index. 
as we now control for a substantially larger part of the variation, their signs remain unchanged. ${ }^{23}$ Crucially, the composite index of bank health remains highly significant.

Table 1. Zombie firms and bank health: baseline results

\begin{tabular}{|c|c|c|c|c|}
\hline & $(1)$ & $(2)$ & (3) & $(4)$ \\
\hline \multicolumn{5}{|c|}{ Panel A - Country-Industry and Year Fixed Effects } \\
\hline Capital & $\begin{array}{l}-0.0022^{* * *} \\
(-2.71)\end{array}$ & $\begin{array}{l}-0.0020^{* *} \\
(-2.27)\end{array}$ & $\begin{array}{l}-0.0020^{*} \\
(-1.94)\end{array}$ & \\
\hline NPLs & $\begin{array}{l}0.0055^{\star * *} \\
(4.11)\end{array}$ & $\begin{array}{l}0.0056^{* * *} \\
(3.59)\end{array}$ & $\begin{array}{l}0.0049^{* * *} \\
(3.40)\end{array}$ & \\
\hline Net Income & & $\begin{array}{c}-0.0008 \\
(-0.27)\end{array}$ & $\begin{array}{c}-0.0022 \\
(-0.75)\end{array}$ & \\
\hline Net Interest Income & & $\begin{array}{c}-0.0042 \\
(-1.30)\end{array}$ & $\begin{array}{r}-0.0021 \\
(-0.58)\end{array}$ & \\
\hline $\begin{array}{l}\text { Maturity Mismatch } \\
(x 10)\end{array}$ & & & $\begin{array}{r}-0.0017 \\
(-1.20)\end{array}$ & \\
\hline $\begin{array}{l}\text { Z-Score } \\
(\times 10)\end{array}$ & & & $\begin{array}{l}-0.0004^{*} \\
(-1.61)\end{array}$ & \\
\hline Bank Health & & & & $\begin{array}{l}-0.0073^{* * *} \\
(-4.95)\end{array}$ \\
\hline Firm Controls & Yes & Yes & Yes & Yes \\
\hline $\mathrm{N}$ & 1534841 & 1534011 & 1508501 & 1508501 \\
\hline $\mathrm{R} 2$ & 0.0784 & 0.0784 & 0.0789 & 0.0786 \\
\hline \multicolumn{5}{|c|}{ Panel B - Country-Industry-Year Fixed Effects } \\
\hline Capital & $\begin{array}{l}-0.0008^{\star \star \star} \\
(-3.30)\end{array}$ & $\begin{array}{l}-0.0006^{\star * *} \\
(-2.49)\end{array}$ & $\begin{array}{l}-0.0004^{* * *} \\
(-1.87)\end{array}$ & \\
\hline NPLS & $\begin{array}{r}-0.0003 \\
(-0.52)\end{array}$ & $\begin{array}{r}0.0000 \\
(-0.05)\end{array}$ & $\begin{array}{r}-0.0002 \\
(-0.42)\end{array}$ & \\
\hline Net Income & & $\begin{array}{c}-0.0006 \\
(-0.66)\end{array}$ & $\begin{array}{c}-0.0011 \\
(-1.07)\end{array}$ & \\
\hline Net Interest Income & & $\begin{array}{l}-0.0046^{\star * *} \\
(-4.38)\end{array}$ & $\begin{array}{l}-0.0037^{\star * *} \\
(-3.58)\end{array}$ & \\
\hline $\begin{array}{l}\text { Maturity Mismatch } \\
(\times 10)\end{array}$ & & & $\begin{array}{c}-0.0003 \\
(-0.69)\end{array}$ & \\
\hline $\begin{array}{l}\text { Z-Score } \\
(\times 10)\end{array}$ & & & $\begin{array}{l}-0.0004^{\star * *} \\
(-3.52)\end{array}$ & \\
\hline Bank Health & & & & $\begin{array}{l}-0.0026^{\star * *} \\
(-5.31)\end{array}$ \\
\hline Firm Controls & Yes & Yes & Yes & Yes \\
\hline $\mathrm{N}$ & 1534412 & 1533582 & 1508076 & 1508076 \\
\hline $\mathrm{R} 2$ & 0.1014 & 0.1014 & 0.1015 & 0.1014 \\
\hline
\end{tabular}

Notes: The dependent variable is a binary indicator of zombie status, based on the NRI definition (see Section 4.2.2). All bank balance sheet variables are expressed in two year lags. All regressions include a control for bank size. Firm controls include firm age, lagged productivity, and a set of dummies for firm employment. Standard Errors clustered at the bank level. $t$ statistics in parentheses. ${ }^{*} p<0.10,{ }^{* *} p<0.05,{ }^{* * *} p<0.01$

45. Table A2 explores the relationship further. Column 1 shows the full results of the baseline regression, with the previously omitted firm level controls shown for exposition purposes. ${ }^{24}$ In turn, columns 2-4 demonstrate that the relationship between zombie status and bank health is virtually unchanged before and after the crisis. This indicates that the forbearance incentives of banks are not simply a cyclical phenomenon. Of course, the aggregate size of the zombie population and the incentives of banks to forbear are cyclical, but the marginal incentive does not seem to vary.

23. The coefficients on NPLs are now much smaller in magnitude and insignificant, and the opposite holds for net interest income.

24. Older firms are more likely to be zombies while firms with high (lagged) productivity are less likely to be zombies. Micro firms (less than ten employees) appear to be the most likely to be zombies, as expected, as firms that do not grow are expected to be more problematic. 


\section{ECO/WKP(2017)65}

46. We can gauge the economic magnitude of the effect by comparing the banks at high and low levels of health. With the NRI definition (column 4 of Table 1, Panel B) of zombies, healthy banks (defined as those one standard deviation above the bank health variable mean) have a 1.2 percentage points lower probability of being associated with zombies compared to weak banks (defined as those one standard deviation below the bank health variable mean). At a mean zombie rate of $13 \%$ in the sample, this translates to roughly $9 \%$ difference in zombie incidence between healthy and weak banks relative to the mean. ${ }^{25}$ It should be noted that this is most likely a conservative estimate, as it removes country-industryyear fixed effects. If, for instance, we include country-sector and year fixed effects (i.e. column 4 of Table 1, Panel A), then healthy banks are 1.8 percentage points less likely to be associated with zombies, a difference in relative incidence of $19 \%$. If we drop year fixed effects, then the corresponding figures rise to 2.2 percentage points and $24 \%$.

47. Table A3 explores the robustness of our baseline estimates. Columns 1-3 show that the relationship between zombie firms and bank health is evident in manufacturing, services and construction. Column 4 shows that the coefficient of bank health is still negative and highly significant, when we apply the interest coverage definition of a zombie firm, instead of NRI (see Section 4.2.2). Column 5 then shows that the results are robust to excluding firms with less than 20 employees, which tend to be underrepresented in ORBIS (see Gal 2013, Kalemli-Ozcan et al. 2015).

48. The final columns of Table A3 provide further evidence that our estimated relationship between zombie firms and weak banks is not simply a product of reverse causality, whereby troubled firms would adversely affect the balance sheets of their banks. While we partly mitigate these concerns above by entering bank health with a two-year lag, controlling for cyclical shocks and running separate pre and postcrisis regressions, an alternate approach is to directly remove potential sources of such reverse causality. Accordingly, Column 6 shows that the estimated relationship is robust to excluding larger firms (i.e. firms with 50 or more employees). This is significant since bank balance sheets are likely to be more sensitive to large firms in distress than smaller firms.

49. Removing large firms, however, may not adequately address endogeneity concerns if a given bank has high indirect exposure, via its connections with a cluster of small firms which together account for a significant share of sectoral activity. Accordingly, column 7 shows that the results are robust to removing firm-year observations for cases with high (above median) bank exposure to specific sectors, defined as the sum of tangible fixed assets of all the firms in a country-sector-year cell with which a bank is linked, as a fraction of bank assets. This is important in the face of a new literature on the role of collateral in amplifying sectoral shocks, either through collateral firesales (real estate or equipment) or through agglomeration effects (Benmelech \& Bergman 2011, Benmelech et al. 2014), and particularly housing in the case of small firms (Banerjee \& Blicke 2016). Jaskowski (2015) makes the theoretical argument that zombie lending may in fact be a rational strategy on the part of banks, who engage in zombie lending as a way of preventing a string of bankruptcies and forced fire sales. With our approach, we can thus control for a specific form of this externality (operating specifically through sectoral effects), and we confirm the robustness of our results.

50. Finally, if a bank was particularly exposed to a sector badly hit by the crisis, then it is possible that the country-industry-year fixed effect will not fully remove any correlation between bank health and the error term, thus inducing reverse causality. As a robustness check, we also run an IV regression for both the NRI and IC definitions (see the final two columns of Table A3), using the pre-crisis lag of bank

25. The magnitude of the effect is slightly larger using the IC definition (Table A3, column 4), where the difference in probability is 1.2 percentage points, which given a mean zombie rate of $9.4 \%$, implies a difference of $13 \%$ in zombie incidence between healthy and weak banks (defined as those one standard deviation above/below the bank health variable mean respectively). 
health as an instrument. The IV coefficient is actually more negative than OLS, suggesting that, if anything, the OLS estimate may be biased is downward. ${ }^{26}$

\subsection{Insolvency regimes shape the link between zombie firms and bank health}

51. Table 2 shows the estimates of equation 2, where we use insolvency regime indicators for two separate years: 2016 (Panel A) and 2010 (Panel B). As predicted, the Bank Health $\times$ INSOL interaction is positive and highly significant (column 1 of Panel A). Column 2 shows that this result is mainly driven by the Barriers to Restructuring (BTR) sub-component and this result is robust to an alternative definition of zombie firms based on the interest coverage ratio (Figure 4). This suggests that in countries with high barriers to restructuring weak firms, improvements in bank health are less likely to translate into fewer zombie firms. This is a central result of the paper: policy initiatives to improve bank health following a financial crisis are more likely to be associated with a decline in zombie congestion in countries where insolvency regimes do not unduly inhibit corporate restructuring since such regimes increase the economic incentives for banks to recognize the loans to zombie firms as non-performing and commence restructuring or foreclosure proceedings. Thus, there are important complementarities between policy initiatives to improve bank health and insolvency reform.

Table 2. Zombie firms and bank health: role of insolvency regimes

\begin{tabular}{|c|c|c|c|c|}
\hline & $\begin{array}{c}(1) \\
\text { insol13 }\end{array}$ & $\begin{array}{c}(2) \\
\text { Barriers } \\
\text { to restructuring } \\
\end{array}$ & $\begin{array}{c}(3) \\
\text { Lack of } \\
\text { prevention } \\
\end{array}$ & $\begin{array}{c}(4) \\
\text { Barriers } \\
\text { to restructuring }\end{array}$ \\
\hline \multicolumn{5}{|l|}{ Panel A - 2016 indicators } \\
\hline Bank Health & $\begin{array}{c}-0.0069^{\star * *} \\
(-3.52)\end{array}$ & $\begin{array}{c}-0.0049^{* * *} \\
(-6.46)\end{array}$ & $\begin{array}{c}-0.0035^{\star * *} \\
(-4.40)\end{array}$ & $\begin{array}{c}-0.0049^{\star \star \star} \\
(-6.29)\end{array}$ \\
\hline Bank Health x INSOL & $\begin{array}{c}0.0141^{* *} \\
(2.39)\end{array}$ & $\begin{array}{c}0.0116^{\star * *} \\
(4.56)\end{array}$ & $\begin{array}{c}0.0028 \\
(1.46)\end{array}$ & $\begin{array}{c}0.0113^{\star \star \star} \\
(4.35)\end{array}$ \\
\hline Bank Health x GDP growth & & & & $\begin{array}{c}-0.0003^{\star *} \\
(-2.53)\end{array}$ \\
\hline Bank Health $x$ INSOL xGDP growth & & & & $\begin{array}{c}0.0005^{*} \\
(1.91) \\
\end{array}$ \\
\hline $\mathrm{N}$ & 1487846 & 1508076 & 1508076 & 1508076 \\
\hline R-squared & 0.1011 & 0.1014 & 0.1014 & 0.1015 \\
\hline \multicolumn{5}{|l|}{ Panel B - 2010 indicators } \\
\hline Bank Health & $\begin{array}{c}-0.0052^{\star *} \\
(-2.54)\end{array}$ & $\begin{array}{c}-0.0053^{\star * *} \\
(-4.17)\end{array}$ & $\begin{array}{c}-0.0028^{* * *} \\
(-3.57)\end{array}$ & $\begin{array}{c}-0.0051^{\star * \star} \\
(-4.11)\end{array}$ \\
\hline Bank Health x INSOL & $\begin{array}{c}0.0061 \\
(1.31)\end{array}$ & $\begin{array}{c}0.0082^{* *} \\
(2.41)\end{array}$ & $\begin{array}{c}0.0004 \\
(0.30)\end{array}$ & $\begin{array}{c}0.0075^{\star *} \\
(2.29)\end{array}$ \\
\hline Bank Health x GDP growth & & & & $\begin{array}{c}-0.0004^{*} \\
(-1.86)\end{array}$ \\
\hline Bank Health x INSOL x GDP growth & & & & $\begin{array}{c}0.0006 \\
(1.44)\end{array}$ \\
\hline $\mathrm{N}$ & 1487846 & 1487846 & 1508076 & 1487846 \\
\hline R-squared & 0.1011 & 0.1011 & 0.1014 & 0.1011 \\
\hline Country-Industry-Year FE & Yes & Yes & Yes & Yes \\
\hline
\end{tabular}

Notes: The dependent variable is a binary indicator of zombie status, based on the NRI definition (see Section 4.2.2). All regressions include firm productivity, firm age, and dummies for size. All regressors are lagged by two years. INSOL12 is the aggregate measure without rights of employees, and INSOL13 includes rights of employees. Standard Errors clustered at the country-sector level. $t$ statistics in parentheses. ${ }^{*} p<0.10,{ }^{* *} p<0.05,{ }^{* * *} p<0.01$

26. Specifically, we instrument for the second lag of bank health using its fifth lag (and so the seventh lag of bank health). As we also control for bank size, we have to instrument for it as well (also using its fifth lag), since bank size is correlated with health, and so failing to instrument for it would violate the exclusion restriction. See Acemoglu and Angrist (2000) for a similar argument. 


\section{ECO/WKP(2017)65}

52. Column 3 shows that the interaction term is not statistically significant for the indicator relating to prevention and streamlining (LPS), which broadly refer to mechanisms that allow firms under temporary distress to avoid entering into insolvency. This should not be surprising: zombie firm problems mostly manifest themselves during slow recoveries after deep recessions brought about by financial crises, when temporary distress is not expected to be of first order importance. Finally, column 4 repeats the exercise with barriers to restructuring, except now augmenting the model to include two additional interaction terms with GDP growth (lagged by two years, as with all other controls). The concern is that, although we include country-industry-sector fixed effects, our model could be capturing (accidental) correlation between the insolvency framework and the size of the downturn. ${ }^{27}$ The main result is robust to this test. In Panel B, we repeat the same exercise for 2010 values of the insolvency framework. The results for barriers to restructuring remain highly statistically significant, although the coefficients for the aggregate measures now become statistically insignificant (though they do maintain the correct sign). ${ }^{28}$

53. One way to illustrate the importance of the insolvency regime is to estimate how much more potent the role of a healthy bank would be if the regime were at the level of best practices. In Figure 4, we plot, for each country in our sample, how the percentage point difference between the zombie-reducing effect of a healthy bank (one standard deviation above the mean) versus a weak bank (one standard deviation below the mean) varies according to the design of the insolvency regime, as measured by the barriers to restructuring indicator (BTR) in 2010. The results in Panel A pertain to the baseline NRI definition of zombie firms which allows us to include Denmark in the exercise, while Panel B shows the corresponding exercise based on the interest coverage definition of zombie firms. As the framework performance is measured in terms of distance from best practice, the blue bars can be interpreted as "room for improvement" in terms of reducing zombie prevalence through reforming BTR. By definition, the best performer in the sample, the United Kingdom, has no room for improvement. For example, Panel B shows that if Estonia - where barriers to corporate restructuring are high - reformed its insolvency regime to the sample minimum (i.e. the United Kingdom), then the reduction in the zombie firm share associated with a two standard deviation improvement in bank health could be around 2.6 percentage points higher than otherwise.

54. We also show, with red diamonds, the position of the country using the value of BTR in 2016, to capture the effect of reforms. Several countries, particularly in the euro periphery, have implemented important reforms, and have gone some way into reducing the incentives of banks to allow zombies to operate. Reforms to insolvency regimes since 2010 in Greece, Slovenia, and Portugal have managed to exploit roughly half of the possibilities offered by improving their BTR, with smaller improvements in Spain and Latvia. Germany has been the most successful in that regard, fully capturing reform opportunities.

27. If, for instance, Denmark, which was one of the countries least-affected by the crisis, had an insolvency framework that entailed low barriers to restructuring, it is possible that the effect we capture is purely driven by such noise.

28. It is unclear why this is the case, but regardless, our focus and intuitive framework relates to barriers to restructuring mostly, and less so to other features of the framework. The changes in the sample occur because of small data availability issues for Denmark. In the 2016 wave, there are no data for insol13, and for the 2010 wave we only have data for LPS. 
ECO/WKP(2017)65

Figure 4. Insolvency regimes shape the link between zombie firms and bank health

Zombie firm share reduction associated with an improvement in bank health according to the insolvency regimes

A: NRI definition of zombie firms

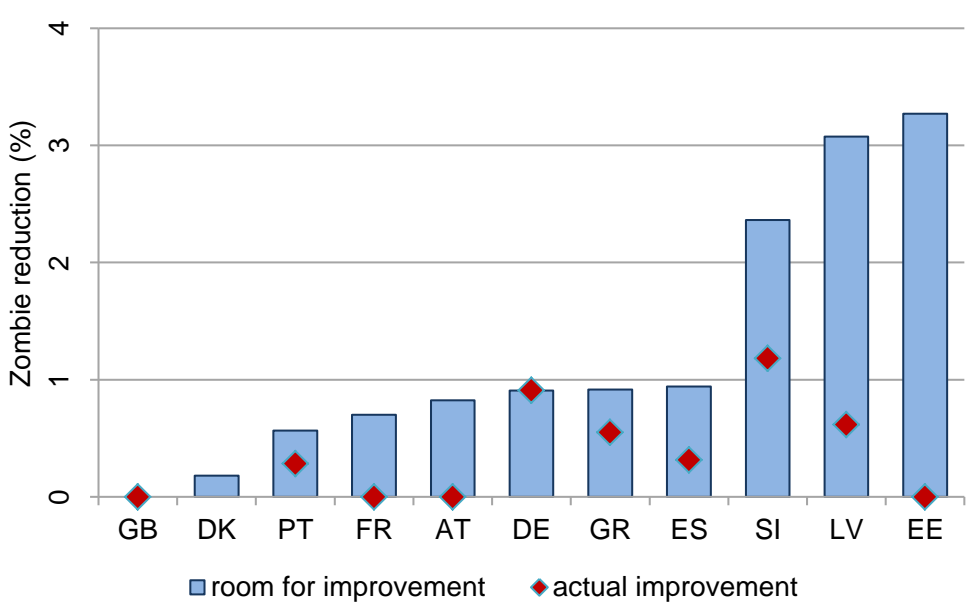

B: Interest coverage definition of zombie firms

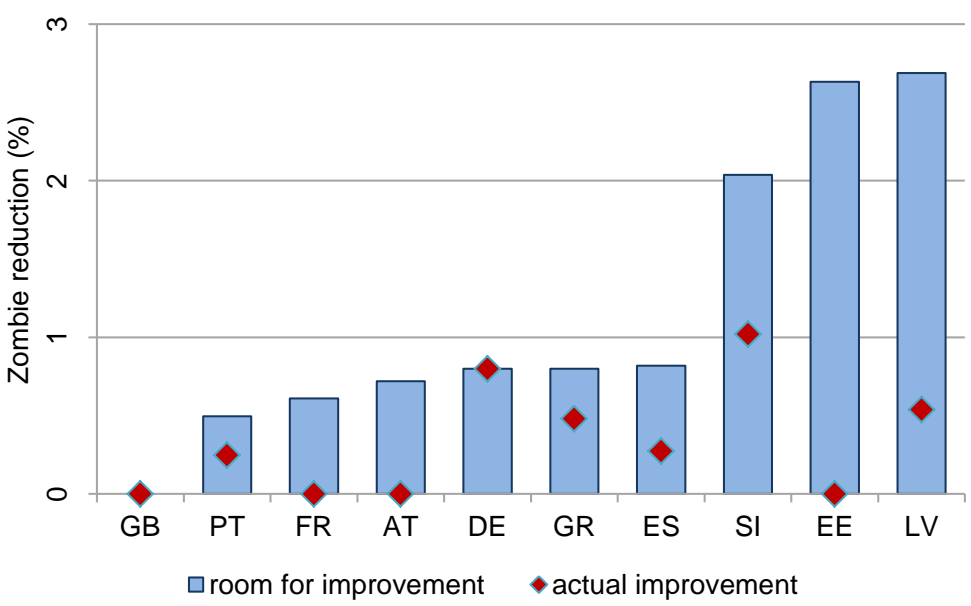

Notes: The graph shows the percentage point difference between the zombie-reducing effect of a healthy bank (one standard deviation above the mean) versus a weak bank (one standard deviation below the mean) under the barriers to restructuring performance (BTR) in 2010. As the BTR indicator is defined as distance from the frontier, the bars indicate the gains from reducing BTR to sample minimum. The red diamonds show the difference in 2016. Given that Denmark lacks insolvency regime indicators for 2010, we assume that the 2010 value is equivalent to the 2016 value and as such do not simulate potential gains from reform. The estimates in Panel A are based on the coefficients in Table 2, while the estimates in Panel B are based on the coefficients in Table A4.

\subsection{Weak banks amplify capital misallocation}

55. Table 3 and Table A5 show the results from the baseline reallocation regression. ${ }^{29}$ Row 1 shows that more productive firms grow at a statistically significantly higher pace, suggesting that the process of capital reallocation enhances aggregate productivity. Moreover, Row 2 shows that bank health acts as an

29. The regressions in this section use a definition of capital using only tangible fixed assets, but if we use total fixed assets instead (including intangibles), the results are broadly similar. These results are available from the authors on request. 
amplifier to the reallocation process: that is, productive firms in industries exposed to healthy banks grow faster than those in industries exposed to weak banks. Table A5 shows that the relationship between bank health and capital reallocation is robust across sectors (Panel A) and was not materially affected by the crisis (Panel C) ${ }^{30}$ The economic magnitude of this effect is significant: an increase in bank health by one standard deviation above its mean would raise the difference in the capital growth between high and low productivity firms (i.e. those one standard deviation above and below the sectoral mean) from $6.6 \%$ to $8.3 \%$. As such, the health of the banking system is important in channelling scarce capital to productive firms and thus underpinning their growth.

Table 3. Capital reallocation, bank health and zombie congestion

\begin{tabular}{|c|c|c|c|}
\hline & $\begin{array}{l}(1) \\
\text { Full Sample }\end{array}$ & $\begin{array}{l}\text { (2) } \\
\text { Full Sample }\end{array}$ & $\begin{array}{l}\text { (3) } \\
\text { Full Sample }\end{array}$ \\
\hline TFP & $\begin{array}{l}0.0547^{\star \star *} \\
(11.63)\end{array}$ & $\begin{array}{l}0.0655^{\star \star *} \\
(9.97)\end{array}$ & $\begin{array}{l}0.0616^{* * *} \\
(9.88)\end{array}$ \\
\hline TFPx Bank Health & $\begin{array}{l}0.0165^{\star * *} \\
(5.35)\end{array}$ & & $\begin{array}{l}0.0147^{\star * *} \\
(4.76)\end{array}$ \\
\hline TFP x Industry Zombie Share & & $\begin{array}{l}-0.1340^{\star * *} \\
(-3.16)\end{array}$ & $\begin{array}{l}-0.0894^{\star *} \\
(-2.29)\end{array}$ \\
\hline Age & $\begin{array}{l}-0.0019 * * * \\
(-6.53)\end{array}$ & $\begin{array}{l}-0.0018^{* * *} \\
(-6.42)\end{array}$ & 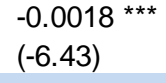 \\
\hline $10<$ Employment $<24$ & $\begin{array}{l}-0.0212^{\star * \star} \\
(-4.25)\end{array}$ & $\begin{array}{l}-0.0213^{\star * *} \\
(-4.27)\end{array}$ & $\begin{array}{l}-0.0213^{\star \star \star} \\
(-4.29)\end{array}$ \\
\hline $25<$ Employment $<49$ & $\begin{array}{l}-0.0154^{* *} \\
(-2.57)\end{array}$ & $\begin{array}{l}-0.0154^{* *} \\
(-2.55)\end{array}$ & $\begin{array}{l}-0.0155^{\star * *} \\
(-2.59)\end{array}$ \\
\hline $49<$ Employment< $<9$ & $\begin{array}{l}-0.0204^{\star} \\
(-1.81)\end{array}$ & $\begin{array}{l}-0.0201^{*} \\
(-1.74)\end{array}$ & $\begin{array}{l}-0.0205^{\star} \\
(-1.81)\end{array}$ \\
\hline $99<$ Employment<249 & $\begin{array}{l}-0.0339^{\star * *} \\
(-2.91)\end{array}$ & $\begin{array}{l}-0.0344^{\star * \star} \\
(-2.93)\end{array}$ & $\begin{array}{l}-0.0344^{\star \star *} \\
(-2.95)\end{array}$ \\
\hline Employment $>250$ & $\begin{array}{l}-0.0306^{\star *} \\
(-2.31)\end{array}$ & $\begin{array}{l}-0.0312^{\star *} \\
(-2.33)\end{array}$ & $\begin{array}{l}-0.0310^{\star *} \\
(-2.32)\end{array}$ \\
\hline $\mathrm{N}$ & 6063141 & 6063141 & 6063141 \\
\hline R-squared & 0.0612 & 0.0608 & 0.0613 \\
\hline Country-Industry-Year FE & Yes & Yes & Yes \\
\hline
\end{tabular}

Note: The dependent variable is log real capital growth. The zombie capital share is constructed using the IC definition of zombie firms (See Section 4.2.2) for sake of comparability with the estimates in Adalet McGowan et al (2017b). All regressors are lagged. Standard Errors clustered at the country-sector level. $t$ statistics in parentheses. ${ }^{*} p<0.10,{ }^{* *} p<0.05,{ }^{* * *} p<0.01$.

56. Next, we jointly examine bank health and zombie congestion. We do this in steps. First, we estimate a capital reallocation model that separately includes a zombie capital $\times$ MFP interaction (which is expected to have a negative coefficient; see Adalet McGowan et al., 2017b); then we include also a bank health $\times$ MFP interaction (which is expected to have a positive coefficient). Finally, Column 3 reports the estimates of the model that includes both interaction terms. Regarding the latter, our expectation is that the inclusion of the bank health $\times$ MFP interaction will reduce the estimated absolute magnitude of the coefficient on the zombie capital $\times$ MFP interaction, as bank health is relevant to both zombie congestion and capital reallocation.

57. As expected from Adalet McGowan et al. (2017b), a higher zombie capital share dampens the efficiency of capital reallocation, by moderating the responsiveness of firm capital growth to (lagged) MFP; moreover, when both interactions are included, they remain highly significant but their absolute

30. There is evidence that reallocation intensity fell during the crisis - which is consistent with the findings of Foster, Grim \& Haltiwanger (2016) for the United States - although this result is driven by the construction sector (Table A5, Panel B). If we broaden the definition of capital to include intangible assets, however, the estimated effects are larger and the MFPxCrisis interaction becomes significant for services. 
magnitude falls, indicating that they are correlated. The coefficient on the zombie capital $\times$ MFP interaction changes from -0.1340 to -0.0894 , a fall in absolute magnitude of around $33 \%$. To the extent that causation runs from bank health to zombie firms, this suggests that around one-third of the distortionary effects of zombie congestion on capital reallocation can be directly attributed to weak banks which allow zombie firms to fester.

58. The estimated coefficient in Column 2 (Table 3) imply that if Spain were able to reduce its zombie capital share to the sample minimum (Slovenia), then the difference in the capital growth between high and low productivity firms (those one standard deviation above and one standard deviation below sectoral mean) would be 1.5 percentages points higher. Similarly, if bank health in Spain were at the level of France in 2012, the gap in capital growth between high and low productivity firms in 2013 would have been roughly 0.8 percentages points higher (based on the estimated coefficient in Column 1, Table 3). These estimated effects are economically significant, since the difference in capital growth between high and low productivity firms fell by 3.6 percentage points ${ }^{31}$ in Spain from 2004 to 2013, consistent with the idea that rising capital misallocation is a key driver of the productivity slowdown in Spain (Gopinath et al 2017) and more generally (see Section 2).

\subsection{Zombie firms and credit crowd-out}

59. Figure 7 shows the binned scatter plot of the sectoral average of the cumulated credit availability variable for healthy firms against the (lagged) share of zombie capital in the same sector, controlling for country-year fixed effects. The left panel shows the plot for bank loans, and the right panel for bank credit lines. We see a clear negative effect of zombie capital on bank credit availability for healthy firms: sectors with a high share of capital tied to zombie firms, within country-year clusters, are associated with more restricted access to bank loans. Regression results in Table 4 (Panel A) confirm the graphical evidence, for both the simple and the composite indicator (which accounts for credit demand). ${ }^{32}$ Given that our sample is size is relatively small (12,781 observations for loans, 8,720 for credit lines) and time panel short, these results should be viewed as indicative.

60. To gauge the magnitude of the effect, it is useful to restrict attention to values at 0 or 1 of the credit availability indicators, since the sample period is one of gradually improving financing conditions. ${ }^{33}$ We then regress this transformed variable on the zombie capital share and various control variables. The results (presented in Panel B of Table 4) show that the estimated log-odds coefficient on the zombie capital share is less than one, which implies that healthy firms are less likely to access credit when the zombie capital share is higher. These estimates imply that a one standard-deviation increase in the zombie capital share is associated with a reduction in the probability of improved loan availability by 1.3 percentage points (with a similar magnitude for credit lines). Compared to an average probability of improvement in loan availability of $18.6 \%$ at the mean of the distribution, the overall effect is modest, but not trivial.

31. Adalet McGowan et al. (2017b), using a longer dataset, document an even larger impact.

32. An alternative way is to directly control for credit demand, using the self-reported indicator of changing credit needs. Doing so is similar in spirit to the Khwaja \& Mian (2008) approach of using firm fixed-effects in lending regressions. Running the basic model with the credit availability indicator with dummies for financing needs gives very similar results.

33. Over the sample period (i.e. 2009 to 2013), we observe a general improvement in lending conditions - save for $2011 \mathrm{H} 2-2012 \mathrm{H} 1$ - which likely tied to the cycle and accommodative monetary policy. 
Figure 5. Zombie congestion and access to finance to healthy firms

Healthy firms' access to credit for each bin of the zombie capital share
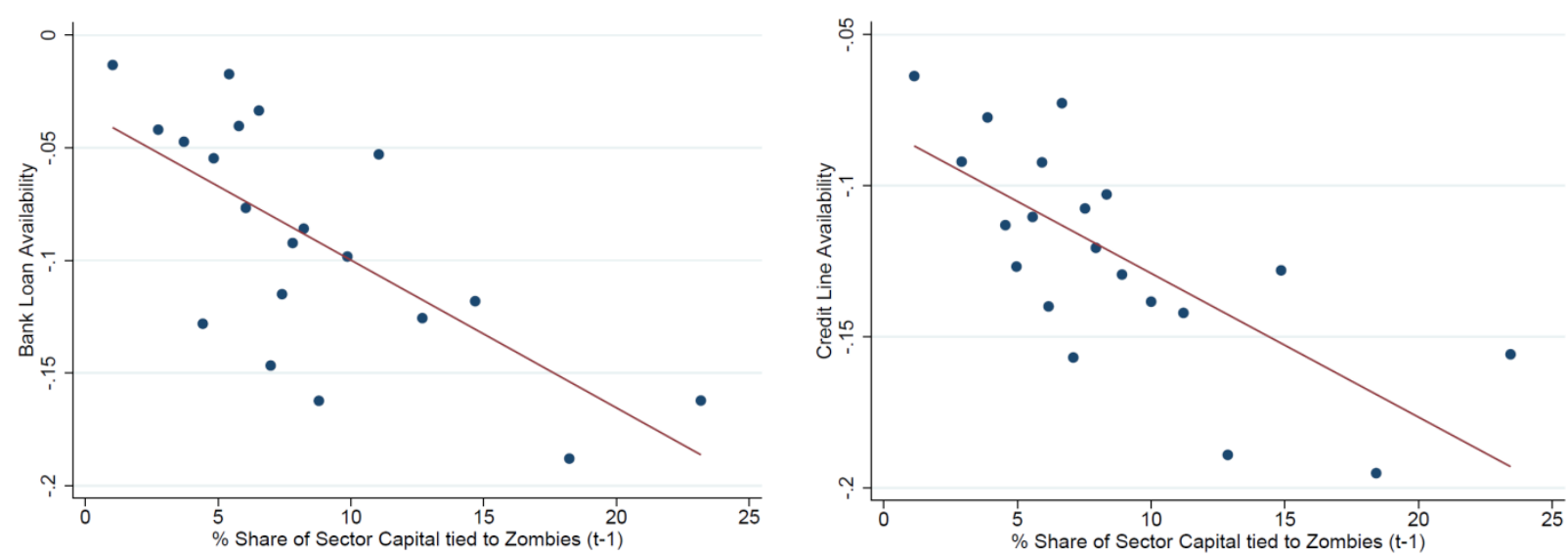

Notes: The plot is a fitted line from regressing credit availability on the share of capital in the sector tied to zombie-firms (based on the IC definition), with country-year fixed effects. The scatters show the mean of the vertical axis variable for each bin of the variable on the horizontal axis. The left panel shows results for bank loans, and the one to the right for credit lines.

Table 4. Credit availability for healthy firms and zombie congestion

\begin{tabular}{|c|c|c|c|c|}
\hline & \multicolumn{2}{|c|}{ A: OLS coefficients } & \multicolumn{2}{|c|}{ B: Ordered logit log-odds ratio coefficients } \\
\hline & $\begin{array}{c}(1) \\
\text { Loans }\end{array}$ & $\begin{array}{c}(2) \\
\text { Credit Lines } \\
\end{array}$ & $\begin{array}{c}(3) \\
\text { Loans }\end{array}$ & $\begin{array}{c}(4) \\
\text { Credit Lines }\end{array}$ \\
\hline \multicolumn{5}{|c|}{ Panel A - Simple Indicator } \\
\hline $\begin{array}{l}\text { Zombie Capital Share } \\
\text { in Sector }\end{array}$ & $\begin{array}{l}-0.0052^{* \star} \\
(-2.20)\end{array}$ & $\begin{array}{l}-0.0048^{\star *} \\
(-2.57)\end{array}$ & $\begin{array}{l}0.9901^{* *} \\
(2.22)\end{array}$ & $\begin{array}{c}0.9889^{* *} \\
(2.55)\end{array}$ \\
\hline Large & $\begin{array}{c}0.1399^{\star \star *} \\
(3.46)\end{array}$ & $\begin{array}{l}0.1435^{\star \star \star} \\
(4.24)\end{array}$ & $\begin{array}{c}1.3434^{* \star \star} \\
(3.55)\end{array}$ & $\begin{array}{c}1.4879^{\star \star \star} \\
(4.78)\end{array}$ \\
\hline Young & $\begin{array}{c}0.0039 \\
(0.15) \\
\end{array}$ & $\begin{array}{l}-0.0144 \\
(-0.49) \\
\end{array}$ & $\begin{array}{l}1.006 \\
(0.10) \\
\end{array}$ & $\begin{array}{c}0.9809 \\
(0.25)\end{array}$ \\
\hline$\overline{\mathrm{N}}$ & 12781 & 8720 & 12781 & 8720 \\
\hline$\underline{\mathrm{R} 2}$ & 0.0414 & 0.0479 & & \\
\hline \multicolumn{5}{|c|}{ Panel B - Composite Indicator } \\
\hline $\begin{array}{l}\text { Zombie Capital Share } \\
\text { in Sector }\end{array}$ & $\begin{array}{c}-0.0068^{\star \star} \\
(-2.13)\end{array}$ & $\begin{array}{l}-0.0044^{\star \star} \\
(-2.08)\end{array}$ & $\begin{array}{r}0.9933 \\
(1.41)\end{array}$ & $\begin{array}{r}0.9904^{*} \\
(1.85)\end{array}$ \\
\hline Large & $\begin{array}{c}0.1328^{* *} \\
(2.02)\end{array}$ & $\begin{array}{l}0.1496^{* * *} \\
(3.62)\end{array}$ & $\begin{array}{l}1.2359^{* *} \\
(2.18)\end{array}$ & $\begin{array}{c}1.4100^{* * *} \\
(4.47)\end{array}$ \\
\hline Young & $\begin{array}{r}-0.0035 \\
(-0.08)\end{array}$ & $\begin{array}{r}-0.0317 \\
(-0.90)\end{array}$ & $\begin{array}{r}0.9682 \\
(0.44)\end{array}$ & $\begin{array}{r}0.9602 \\
(0.45)\end{array}$ \\
\hline $\mathrm{N}$ & 10101 & 7820 & 10101 & 7820 \\
\hline $\mathrm{R} 2$ & 0.0336 & 0.0507 & & \\
\hline Country-Year FE & Yes & Yes & Yes & Yes \\
\hline
\end{tabular}

Notes: The dependent variable is the cumulated indicator of bank credit availability (loans or credit lines) as described in the text, truncated at \pm 3 , where 0 indicates no change, and higher values improvement in availability. The ordered logit coefficients are expressed in log-odds ratio, whereby values less than 1 indicates that credit is less likely to be available for a given increase in the independent variable of interest The zombie capital share is constructed using the IC definition of zombie firms (See Section 4.2.2). Standard Errors clustered at the country-sector level. $t$ statistics in parentheses. ${ }^{*} p<0.10,{ }^{* *} p<0.05,{ }^{* * *} p<0.01$

61. The negative relationship between credit availability to healthy firms and zombie capital in a sector could either be the result of lower profitability of potential investments due to zombie congestion, or limited lending capacity of banks exposed to this particular sector due to zombie forbearance. However, our sense is that it is more likely to reflect the former. Banks are unlikely, on average, to be overtly exposed to a specific sector so much so that exposure to zombie firms in that sector substantially hurts their balance sheet. For instance, the median bank exposure to a specific country-sector-year cell, given by the total tangible capital of the firms in that particular sector associated with any given bank, is approximately 
$0.12 \%$ of total bank assets. This makes it unlikely that losses from loans to zombies in a given sector would affect lending capacity to a healthy firm in the same sector. Of course, this is not to imply that crowd-out cannot occur through the bank balance sheet. In fact, contrary to the zombie congestion case, credit crowdout may spillover to other sectors, but this hypothesis is difficult to address with the data at hand.

\section{Conclusion}

62. This paper presents robust evidence that zombie firms are more likely to be connected to weak banks. We use two different zombie definitions with very similar results, and none of them depends on new lending, but indebtedness, so we account for forbearance. We then show that the effect of bank health on zombie status is amplified under insolvency regimes that do not unduly inhibit corporate restructuring. Thus efficient insolvency policies, together with healthier banks, would appear to be important in resolving the zombie problem, thereby raising aggregate productivity growth.

63. Next, we show that healthy banks foster productivity-enhancing capital reallocation, the process by which productive firms grow relatively more. We also show that about one-third of the negative effects of zombie congestion on the efficiency of reallocation, identified in earlier work, could be attributed to weak banks.

64. Finally, we offer some evidence on the mechanism behind zombie congestion. The negative zombie effects on reallocation and productivity have been attributed to congestion effects (competition) or the credit crowd-out. However, little is known about the crowd-out channel. We provide some evidence of the existence of credit crowd-out, using SAFE. Results are indicative due to the small sample, but we document a modest but statistically significant effect: healthy firms report smaller improvements in access to finance in sectors with a high share of capital tied to zombie firms. This would suggest that zombie congestion works mostly through reduced profits for healthy firms, which reduce expected return on projects, and as a result lead to worse borrowing opportunities.

65. Set in the broader context of the productivity slowdown and the aftermath of the global financial crisis, which has hurt bank and firm balance sheets, our results can carry important implications. As rising capital misallocation has been shown to be a key driver of the aggregate productivity slowdown (Gopinath et al 2017), while zombie congestion is intimately linked to the other key micro dimensions to the slowdown, such as rising productivity dispersion (Andrews et al 2016) and declining business dynamism (Decker et al. 2016), identifying and correcting the distortions which disrupt the natural market selection mechanism is vital to reviving productivity growth.

66. The results imply that in order to facilitate the unwinding of the zombie problem, it is essential that bank balance sheets are strong, underlining the need for fast recapitalizations after crises and other measures to reduce NPLs. But strengthening banks is an insufficient policy response while insolvency regimes remain hostile to the orderly restructuring and resolution of weak firms. Thus, in countries with weak banks and weak insolvency regimes, efforts to improve banks' health should be accompanied by appropriate insolvency reforms to reduce impediments to corporate restructuring. At the same time, countries with strong firms and banks should view the establishment of an efficient insolvency framework as equivalent to a macro-prudential tool, to be used in conjunction with post-crisis recapitalisation. 


\section{REFERENCES}

Acemoglu, D., U. Akcigit, N. Bloom and W. Kerr (2013), "Innovation, Reallocation and Growth", NBER Working Papers, No. 18993.

Acemoglu, D. and J. Angrist (2000), "How Large Are Human-Capital Externalities? Evidence from Compulsory Schooling Laws", NBER Macroeconomics Annual, Vol. 15, 9-59.

Acharya, V., Eisert, T., Eufinger, C. \& Hirsch, C. (2017), "Whatever it takes: The Real Effects of Unconventional Monetary Policy", Mimeo.

Adalet McGowan, M. and D. Andrews (2016), "Insolvency Regimes and Productivity Growth: A Framework for Analysis", OECD Economics Department Working Papers, No. 1309.

Adalet McGowan, M., D. Andrews and V. Millot (2017a), "Insolvency Regimes, Zombie Firms and Capital Reallocation”, OECD Economics Department Working Papers, No. 1399.

Adalet McGowan, M., D. Andrews and V. Millot (2017b), "The Walking Dead: Zombie Firms and Productivity Performance in OECD Countries", OECD Economics Department Working Papers, No. 1372.

Adalet McGowan, M., D. Andrews and V. Millot (2017c), "Insolvency Regimes, Technology Diffusion and Productivity Growth: Evidence from Firms in OECD Countries", OECD Economics Department Working Papers, forthcoming.

Akiyoshi, F. \& Kobayashi, K. (2010), "Banking Crisis and Productivity of Borrowing Firms: Evidence from Japan", Japan and the World Economy 22(3), 141-150.

Andrews, D., Criscuolo, C. \& Gal, P. (2016), "The Best versus the Rest: The Global Productivity Slowdown, Divergence across Firms and the Role of Public Policy", OECD Productivity Working Paper, No. 2.

Australian Productivity Commission (2015), "Business Set-up, Transfer and Closure", Draft Report, Canberra.

Baily, M. N., Hulten, C. \& Campbell, D. (1992), "Productivity dynamics in manufacturing plants", Brookings Papers on Economic Activity: Microeconomics pp. 187-249.

Baldwin, J. \& Gu, W. (2006), "Competition, firm turnover and productivity growth", Research Paper Series, Statistics Canada.

Banerjee, R. \& Blicke, K. (2016), "Housing Collateral and Small Firm Activity in Europe", BIS Working Paper No. 575.

Bank of England (2013), "Inflation Report", Bank of England, London.

Bank of Korea (2013), "Financial Stability Report", Bank of Korea, Seoul.

Bartelsman, E., J. Haltiwanger and S. Scarpetta (2013), "Cross-Country Differences in Productivity: The Role of Allocation and Selection", American Economic Review 103(1), 305-334.

Benmelech, E. \& Bergman, N. (2011), "Bankruptcy and the Collateral Channel”, Journal of Finance 66(2), $337-378$.

Benmelech, E., Bergman, N., Milanez, A. \& Mukharlyamov, V. (2014), "The Agglomeration of Bankruptcy", NBER Working Paper, No. 20254.

Berlingieri, G., Blanchenay, P. \& Criscuolo, C. (2017), "The Great Divergence(s)", OECD Science, Technology and Industry Policy Papers. 
Bernanke, B., Boivin, J. \& Eliasz, P. (2005), "Measuring the Effects of Monetary Policy: A FactorAugmented Vector Autoregressive (FAVAR) Approach", Quarterly Journal of Economics 120, $387-422$.

Caballero, R., Hoshi, T. \& Kashyap, A. (2008), “Zombie Lending and Depressed Restructuring in Japan”, American Economic Review 98(5), 1943-1977.

Chodorow-Reich, G (2014), "The Employment Effects of Credit Market Disruptions: Firm-Level Evidence from the 2008-09 Financial Crisis", Quarterly Journal of Economics 129(1), 1-59.

Criscuolo, C., Gal, P. \& Menon, C. (2014), "The Dynamics of Employment Growth: New Evidence from 18 Countries", OECD Science, Technology and Industry Policy Papers.

Decker, R., Haltiwanger, J., Jarmin, R. S. \& Miranda, J. (2016), "Changing Business Dynamism and Productivity: Shocks vs. Responsiveness", Unpublished Manuscript.

Decker, R., Haltiwanger, J., Jarmin, R. S. \& Miranda, J. (2017), "Declining Dynamism, Allocative Efficiency, and the Productivity Slowdown", American Economic Review: Papers and Proceedings 107(5), 322-326.

Disney, R., Haskel, J. \& Heden, Y. (2003), "Restructuring and Productivity Growth in UK Manufacturing", Economic Journal pp. 666-694.

Ferrando, A., Griesshaber, N., Koehler-Ulbrich, P., Perez-Duarte, S. \& Schmitt, N. (2013), "Measuring the opinion of firms on the supply and demand of external financing in the euro area", IFC Bulletin, Bank for International Settlements 36, 283-303.

Foster, L., Grim, C. \& Haltiwanger, J. (2016), "Reallocation in the Great Recession: Cleansing or Not?", Journal of Labor Economics 34(1), S293-S331.

Foster, L., Grim, C., Haltiwanger, J. \& Wolf, Z. (2016), "Firm-Level Dispersion in Productivity: Is the Devil in the Details?", American Economic Review: Papers and Proceedings 106(5), 95-98.

Foster, L., Haltiwanger, J. \& Krizan, C. J. (2006), "Market Selection, Reallocation, and Restructuring in the U. S Retail Trade Sector in the 1990s", Review of Economics and Statistics 88(4), 748-758.

Gal, P. (2013), "Measuring Total Factor Productivity at the Firm Level using OECD-ORBIS", OECD Economics Department Working Papers No. 1049.

Gamberoni, E., Giordano, C. \& Lopez-Garcia, P. (2016), "Capital and Labour (mis)allocation in the Euro Area: Some Stylized Facts and Determinants", ECB Working Paper.

Gopinath, G., Kalemli-Ozcan, S., Karabarbounis, L. \& Villegas-Sanchez, C. (2017), "Capital Allocation and Productivity in South Europe", Quarterly Journal of Economics, forthcoming.

Hiatt, S., Sine, W. \& Tolbert, P. (2009), "From Pabst to Pepsi: The Deinstitutionalization of Social Practices and the Creation of Entrepreneurial Opportunities", Administrative Science Quarterly pp. 635-667.

Hoetker, G. \& Agarwal, R. (2007), “Death Hurts, But It Isn't Fatal: The Postexit Diffusion of Knowledge Created by Innovative Companies", Academy of Management Journal pp. 446-467.

Hopenhayn, H. (1992), "Entry, Exit, and Firm Dynamics in Long Run Equilibrium”, Econometrica 60(5), $1127-1150$.

Hsieh, C.-T. \& Klenow, P. J. (2009), "Misallocation and Manufacturing TFP in China and India", The Quarterly Journal of Economics 124(4), 1403-1448.

Jaskowski, M. (2015), "Should zombie lending always be prevented?", International Review of Economics \& Finance 40C, 191-203. 


\section{ECO/WKP(2017)65}

Kalemli-Ozcan, S., Laeven, L. \& Moreno, D. (2015), "Debt Overhang, Rollover Risk and Investment in Europe", Mimeo, University of Maryland.

Khwaja, A. I. \& Mian, A. (2008), "Tracing the impact of bank liquidity shocks: Evidence from an emerging market", American Economic Review 98(4), 1413-42.

Kwon, H., Narita, F. \& Narita, M. (2015), "Resource reallocation and zombie lending in Japan in the 1990s", Review of Economic Dynamics 18, 709-732.

Marinc, M. \& Vlahu, R. (2012), The Economics of Bank Bankruptcy Law, Springer-Verlag, BerlinHeidelberg.

Nishimura, K., Nakajima, T. \& Kiyota, K. (2005), "Does the Natural Selection Mechanism Still Work in Severe Recessions? Examination of the Japanese Economy in the 1990s", Journal of Economic Behavior and Organization 58, 53-78.

Okada, T. \& Horioka, C. (2008), "A Comment on Nishimura, Nakajima, and Kiyota"s "Does the Natural Selection Mechanism Still Work in Severe Recessions? Examination of the Japanese Economy in the 1990s"“, Journal of Economic Behavior \& Organization 67, 517-520.

Ollivaud, P., Y. Guillemette and D. Turner (2016), "The Links between Weak Investment and the Slowdown in OECD Productivity and Potential Output Growth", OECD Economics Department Working Papers, No. 1304.

Peek, J. \& Rosengren, E. (2005), "Unnatural Selection: Perverse Incentives and the Misallocation of Credit in Japan", American Economic Review 95(4), 1144-1166.

Sakai, K., Uesugi, I. \& Watanabe, T. (2010), "Firm Age and the Evolution of Borrowing Costs: Evidence from Japanese Small Firms", Journal of Banking \& Finance 34(8), 1970-1981.

Schivardi, F., Sette, E. \& Tabellini, G. (2017), "Credit Misallocation During the European Financial Crisis", Bank of Italy Working Paper.

Smith, D. \& Stromberg, P. (2005), Maximizing the Value of Distressed Assets: Bankruptcy Law and the Efficient Reorganization of Firms, Cambridge University Press.

Storz, M., Koetter, M., Setzer, R. \& Westphal, A. (2017), "Do We Want these two to Tango? On Zombie Firms and Stressed Banks in Europe", Mimeo, ECB.

Syverson, C. (2011), “What Determines Productivity?” Journal of Economic Literature 49(2), 326-365. 
APPENDIX A: ADDITIONAL TABLES AND FIGURES

Table A1. Summary statistics

\begin{tabular}{lrrrrrr}
\hline & N & Mean & Median & S.D. & Min & \multicolumn{2}{c}{ Max } \\
\hline Firms & & & & & & \\
$\quad$ Tangible Fixed Assets (1000s) & $2,141,170$ & 8504 & 135 & 298754 & 0 & $1.28 \mathrm{E}+08$ \\
$\quad$ Tangibility & $2,140,963$ & 0.217 & 0.132 & 0.229 & 0 & 11.523 \\
$\quad$ Number of employees & $2,202,818$ & 111 & 11 & 1860 & 1 & 477100 \\
Zombie (IC) & $1,854,147$ & 0.073 & & 0.26 & 0 & 1 \\
Zombie (NRI) & $2,093,000$ & 0.098 & & 0.298 & 0 & 1
\end{tabular}

Number of employees

\begin{tabular}{|c|c|}
\hline Below 10 & $1,031,694$ \\
\hline Between 10 and 19 & 385,345 \\
\hline Between 20 and 49 & 384,261 \\
\hline Between 50 and 99 & 168,819 \\
\hline Between 100 and 249 & 129,083 \\
\hline Over 250 & 103,616 \\
\hline
\end{tabular}

Banks

\begin{tabular}{|lrrrrrr} 
Banks & & & & & \\
Bank Health & $2,202,818$ & -0.139 & 0.02 & 1.649 & -8.964 & 5.592 \\
\hline Tangible Common Equity (\% asse & $2,202,818$ & 5.38 & 4.81 & 3.86 & -72.8 & 98.96 \\
\hline NPLs(\% assets) & $2,202,818$ & 1.6 & 0.831 & 2.48 & 0 & 90.61 \\
ROAA & $2,202,818$ & 0.275 & 0.36 & 1.32 & -58.11 & 29.89 \\
\hline Z-Score & $2,202,818$ & 37.94 & 14.95 & 83.04 & -34.89 & 3891.32 \\
\hline Net Income (\% assets) & $2,202,818$ & 0.252 & 0.356 & 1.373 & -82.24 & 25 \\
Net Interest Income (\% assets) & $2,202,818$ & 1.617 & 1.58 & 0.82 & -3.13 & 29.29 \\
\hline Deposits (\% liabilities) & $2,202,818$ & 53.431 & 51.68 & 19.2 & 0 & 100 \\
\hline
\end{tabular}


Table A2. Zombie firms and bank health: role of the crisis

\begin{tabular}{|c|c|c|c|c|}
\hline & $\begin{array}{l}\text { (1) } \\
\text { Full Sample }\end{array}$ & $\begin{array}{l}(2) \\
\text { Pre-Crisis }\end{array}$ & $\begin{array}{l}\text { (3) } \\
\text { Crisis }\end{array}$ & $\begin{array}{l}\text { (4) } \\
\text { Full Sample }\end{array}$ \\
\hline Bank Health & $\begin{array}{l}-0.0026^{\star \star \star} \\
(-5.31)\end{array}$ & $\begin{array}{l}-0.0022^{\star \star} \\
(-2.43)\end{array}$ & $\begin{array}{l}-0.0028^{\star \star \star} \\
(-4.75)\end{array}$ & $\begin{array}{l}-0.0028^{\star \star *} \\
(-3.52)\end{array}$ \\
\hline Crisis $\times$ Bank Health & & & & $\begin{array}{l}0.0002 \\
(0.29)\end{array}$ \\
\hline Age & $\begin{array}{l}0.0005^{\star \star *} \\
(5.60)\end{array}$ & $\begin{array}{l}0.0004^{* \star *} \\
(4.72)\end{array}$ & $\begin{array}{l}0.0005^{\star \star \star} \\
(5.69)\end{array}$ & $\begin{array}{l}0.0005^{\star \star *} \\
(5.60)\end{array}$ \\
\hline Labor Productivity & $\begin{array}{l}-0.0377^{\star \star \star} \\
(-10.41)\end{array}$ & $\begin{array}{l}-0.0282^{\star \star \star} \\
(-15.52)\end{array}$ & $\begin{array}{l}-0.0432^{\star * *} \\
(-9.24)\end{array}$ & $\begin{array}{l}-0.0377^{\star \star \star} \\
(-10.41)\end{array}$ \\
\hline 10<Employment<24 & $\begin{array}{l}-0.0095^{\star \star \star} \\
(-3.73)\end{array}$ & $\begin{array}{l}-0.0074^{\star \star} \\
(-2.15)\end{array}$ & $\begin{array}{l}-0.0104^{\star * *} \\
(-4.37)\end{array}$ & $\begin{array}{l}-0.0095^{\star \star \star} \\
(-3.73)\end{array}$ \\
\hline $25<$ Employment $<49$ & $\begin{array}{l}-0.0048^{*} \\
(-1.65)\end{array}$ & $\begin{array}{l}-0.0015 \\
(-0.58)\end{array}$ & $\begin{array}{l}-0.0067^{*} \\
(-1.83)\end{array}$ & $\begin{array}{l}-0.0048^{*} \\
(-1.65)\end{array}$ \\
\hline $49<$ Employment< 99 & $\begin{array}{l}0.0104^{* *} \\
(2.42)\end{array}$ & $\begin{array}{l}0.0149^{* * *} \\
(5.23)\end{array}$ & $\begin{array}{l}0.0074 \\
(1.20)\end{array}$ & $\begin{array}{l}0.0104^{* *} \\
(2.42)\end{array}$ \\
\hline $99<$ Employment<249 & $\begin{array}{l}0.0166^{\star * *} \\
(3.01)\end{array}$ & $\begin{array}{l}0.0210^{* * *} \\
(4.09)\end{array}$ & $\begin{array}{l}0.0139^{*} \\
(1.86)\end{array}$ & $\begin{array}{l}0.0166^{* * *} \\
(3.01)\end{array}$ \\
\hline Employment $>250$ & $\begin{array}{l}0.0138^{\star \star} \\
(2.45) \\
\end{array}$ & $\begin{array}{l}0.0183^{\star \star \star} \\
(4.41)\end{array}$ & $\begin{array}{l}0.0111 \\
(1.45) \\
\end{array}$ & $\begin{array}{l}0.0138^{\star \star} \\
(2.45) \\
\end{array}$ \\
\hline Country-Industry-Year FE & Yes & Yes & Yes & Yes \\
\hline $\begin{array}{l}\mathrm{N} \\
\mathrm{R} 2\end{array}$ & $\begin{array}{r}150807 \\
0.101\end{array}$ & $\begin{array}{r}578756 \\
0.0442\end{array}$ & $\begin{array}{r}929320 \\
0.1043\end{array}$ & $\begin{array}{r}1508076 \\
0.1014\end{array}$ \\
\hline
\end{tabular}

Notes: The dependent variable is a binary indicator of zombie status. All bank balance sheet variables are expressed in two years lags. All regressions include a control for bank size. Firm controls include firm age, lagged productivity, and a set of dummies for firm employment.

Standard Errors clustered at the country-sector level. $t$ statistics in parentheses.

${ }^{*} p<0.10,{ }^{* *} p<0.05,{ }^{* \star *} p<0.01$ 
ECO/WKP(2017)65

Table A3. Zombie firms and bank health: robustness tests

\begin{tabular}{|c|c|c|c|c|c|c|c|c|c|}
\hline & $\begin{array}{c}\text { (1) } \\
\text { Manufacturing }\end{array}$ & $\begin{array}{c}(2) \\
\text { Services }\end{array}$ & $\begin{array}{c}\text { (3) } \\
\text { Construction }\end{array}$ & $\begin{array}{l}(4) \\
\text { IC }\end{array}$ & $\begin{array}{c}(5) \\
\text { Over } 20\end{array}$ & $\begin{array}{c}(6) \\
\text { Below } 50\end{array}$ & $\begin{array}{c}(7) \\
\text { Low Exposure }\end{array}$ & $\begin{array}{c}(8) \\
\mathrm{IV}-\mathrm{NRI}\end{array}$ & $\begin{array}{c}(9) \\
\text { IV - IC }\end{array}$ \\
\hline Bank Health & $\begin{array}{l}-0.0026^{\star \star \star} \\
(-3.19)\end{array}$ & $\begin{array}{l}-0.0023^{\star \star *} \\
(-3.59)\end{array}$ & $\begin{array}{l}-0.0040^{\star \star \star} \\
(-4.75)\end{array}$ & $\begin{array}{c}-0.0026^{\star \star \star} \\
(-5.31)\end{array}$ & $\begin{array}{l}-0.0033^{\star \star \star} \\
(-3.94)\end{array}$ & $\begin{array}{c}-0.0025^{\star \star \star} \\
(-5.18)\end{array}$ & $\begin{array}{c}-0.0029^{\star \star \star} \\
(-4.75)\end{array}$ & $\begin{array}{c}-0.0054^{* \star} \\
(-2.45)\end{array}$ & $\begin{array}{l}-0.0051^{* *} \\
(-2.12)\end{array}$ \\
\hline Age & $\begin{array}{c}0.0003^{\star *} \\
(2.40)\end{array}$ & $\begin{array}{c}0.0006^{\star \star \star} \\
(7.22)\end{array}$ & $\begin{array}{c}0.0003^{* * \star} \\
(3.50)\end{array}$ & $\begin{array}{c}0.0005^{\star \star *} \\
(5.60)\end{array}$ & $\begin{array}{c}0.0003^{* * *} \\
(4.43)\end{array}$ & $\begin{array}{c}0.0007^{\star \star \star} \\
(6.97)\end{array}$ & $\begin{array}{c}0.0005^{\star * \star} \\
(5.39)\end{array}$ & $\begin{array}{c}0.0006^{\star \star \star} \\
(5.10)\end{array}$ & $\begin{array}{l}0.0008^{\star \star *} \\
(7.11)\end{array}$ \\
\hline Labor Productivity & $\begin{array}{l}-0.0503^{\star \star \star} \\
(-11.55)\end{array}$ & $\begin{array}{l}-0.0399^{\star \star *} \\
(-8.98)\end{array}$ & $\begin{array}{l}-0.0218^{\star \star \star} \\
(-7.87)\end{array}$ & $\begin{array}{l}-0.0377^{\star \star *} \\
(-10.41)\end{array}$ & $\begin{array}{l}-0.0229^{* \star *} \\
(-9.78)\end{array}$ & $\begin{array}{l}-0.0414^{\star \star \star} \\
(-11.20)\end{array}$ & $\begin{array}{l}-0.0371^{\star \star \star} \\
(-12.04)\end{array}$ & $\begin{array}{c}-0.0487^{\star \star \star} \\
(-12.94)\end{array}$ & $\begin{array}{l}-0.0336^{\star \star \star} \\
(-9.71)\end{array}$ \\
\hline $10<$ Employment<24 & $\begin{array}{l}-0.0072^{\star \star} \\
(-2.45)\end{array}$ & $\begin{array}{l}-0.0075^{\star \star \star} \\
(-2.88)\end{array}$ & $\begin{array}{l}-0.0151^{\star \star \star} \\
(-3.44)\end{array}$ & $\begin{array}{c}-0.0095^{\star \star \star} \\
(-3.73)\end{array}$ & & & $\begin{array}{c}-0.0122^{\star \star \star} \\
(-5.05)\end{array}$ & $\begin{array}{c}-0.0114^{\star \star \star} \\
(-3.49)\end{array}$ & $\begin{array}{l}-0.0003 \\
(-0.10)\end{array}$ \\
\hline $25<$ Employment $<49$ & $\begin{array}{l}-0.0010 \\
(-0.30)\end{array}$ & $\begin{array}{l}-0.0008 \\
(-0.26)\end{array}$ & $\begin{array}{c}-0.0155^{\star \star \star} \\
(-3.57)\end{array}$ & $\begin{array}{l}-0.0048^{*} \\
(-1.65)\end{array}$ & & & $\begin{array}{c}-0.0116^{\star \star \star} \\
(-3.61)\end{array}$ & $\begin{array}{l}-0.0073 \\
(-1.44)\end{array}$ & $\begin{array}{l}0.0049 \\
-1.13\end{array}$ \\
\hline 49<Employment<99 & $\begin{array}{c}0.0277^{\star \star \star} \\
(5.84)\end{array}$ & $\begin{array}{c}0.0101^{* *} \\
(1.99)\end{array}$ & $\begin{array}{l}-0.0119^{\star *} \\
(-2.39)\end{array}$ & $\begin{array}{c}0.0104^{\star \star} \\
(2.42)\end{array}$ & & & $\begin{array}{l}0.0428 \\
(1.14)\end{array}$ & $\begin{array}{c}0.0041 \\
-0.62\end{array}$ & $\begin{array}{c}0.0221^{\star \star \star} \\
-4.24\end{array}$ \\
\hline $99<$ Employment<249 & $\begin{array}{c}0.0411^{\star \star \star *} \\
(7.06)\end{array}$ & $\begin{array}{c}0.0122^{*} \\
(1.95)\end{array}$ & $\begin{array}{r}-0.0098 \\
(-1.59)\end{array}$ & $\begin{array}{c}0.0166^{\star \star \star} \\
(3.01)\end{array}$ & & & $\begin{array}{l}0.0709 \\
(1.46)\end{array}$ & $\begin{array}{c}-0.0012 \\
(-0.16)\end{array}$ & $\begin{array}{c}0.0276^{\star \star \star} \\
-4.85\end{array}$ \\
\hline Employment > 250 & $\begin{array}{c}0.0489^{\star \star \star} \\
(9.35)\end{array}$ & $\begin{array}{l}0.0058 \\
(0.91)\end{array}$ & $\begin{array}{c}-0.0214^{\star \star \star} \\
(-3.13)\end{array}$ & $\begin{array}{c}0.0138^{\star \star} \\
(2.45)\end{array}$ & & & $\begin{array}{l}0.0082 \\
(1.29)\end{array}$ & $\begin{array}{c}-0.0134^{\star} \\
(-1.66)\end{array}$ & $\begin{array}{c}0.0215^{\star \star \star} \\
-2.71\end{array}$ \\
\hline Employment & & & & & $\begin{array}{l}0.0000 \\
(-0.96)\end{array}$ & $\begin{array}{c}0.0000^{* \star *} \\
(3.54)\end{array}$ & & & \\
\hline Employment square & & & & & $\begin{array}{l}0.0000 \\
(0.19) \\
\end{array}$ & $\begin{array}{c}-0.0000^{\star \star \star} \\
(-2.71) \\
\end{array}$ & & & \\
\hline Country-Industry-Year FE & Yes & Yes & Yes & Yes & Yes & Yes & Yes & Yes & Yes \\
\hline $\mathrm{N}$ & 357421 & 889924 & 260731 & 1508076 & 556375 & 1214627 & 679161 & 510859 & 466875 \\
\hline $\mathrm{R} 2$ & 0.107 & 0.092 & 0.1331 & 0.1013 & 0.0798 & 0.1132 & 0.1132 & & \\
\hline Kleibergen-Paap F-statistic & & & & & & & & 13.322 & 14.661 \\
\hline
\end{tabular}

Notes: The dependent variable is a binary indicator of zombie status based on the NRI definition, with the exception of column 4 and 9. All bank balance sheet variables are expressed in two years lags. All regressions include a control for bank size. Firm controls include firm age, lagged productivity, and a set of dummies for firm employment.

Standard Errors clustered at the country-sector level. $t$ statistics in parentheses. The Stock-Yogo critical values for $10 \%$ maximal IV size are 7.03 - higher values of the Kleibergen-Papp F-statistic indicate rejection of weak-instrument null.

${ }^{*} p<0.10,{ }^{* *} p<0.05,{ }^{* * *} p<0.01$ 
Table A4. Zombie firms, bank health and insolvency regimes: robustness

Robustness to interest coverage (IC) definition of zombie firms

\begin{tabular}{|c|c|c|c|c|}
\hline & $\begin{array}{c}(1) \\
\text { insol13 }\end{array}$ & $\begin{array}{c}\text { (2) } \\
\text { Barriers } \\
\text { to restructuring } \\
\end{array}$ & $\begin{array}{c}\text { (3) } \\
\text { Lack of } \\
\text { prevention }\end{array}$ & $\begin{array}{c}\text { (4) } \\
\text { Barriers } \\
\text { to restructuring }\end{array}$ \\
\hline \multicolumn{5}{|l|}{ Panel A - 2016 indicators } \\
\hline Bank Health & $\begin{array}{c}-0.0067^{* * *} \\
(-3.45)\end{array}$ & $\begin{array}{c}-0.0053^{\star * *} \\
(-5.48)\end{array}$ & $\begin{array}{c}-0.0033^{* * *} \\
(-3.56)\end{array}$ & $\begin{array}{c}-0.0053^{\star * *} \\
(-5.42)\end{array}$ \\
\hline Bank Health x INSOL & $\begin{array}{c}0.0141^{\star *} \\
(2.39)\end{array}$ & $\begin{array}{c}0.0144^{* * *} \\
(4.43)\end{array}$ & $\begin{array}{l}0.003 \\
(1.17)\end{array}$ & $\begin{array}{c}0.0141^{* * *} \\
(4.28)\end{array}$ \\
\hline Bank Health x GDP growth & & & & $\begin{array}{c}-0.0003^{* * *} \\
(-3.67)\end{array}$ \\
\hline Bank Health x INSOL xGDP growth & & & & $\begin{array}{c}0.0007^{* * *} \\
(2.76)\end{array}$ \\
\hline $\mathrm{N}$ & 1387620 & 1389844 & 1389844 & 1389844 \\
\hline R-squared & 0.0583 & 0.0585 & 0.0585 & 0.0585 \\
\hline \multicolumn{5}{|l|}{ Panel B - 2010 indicators } \\
\hline Bank Health & $\begin{array}{c}-0.0038^{* *} \\
(-2.19)\end{array}$ & $\begin{array}{c}-0.0049^{* * *} \\
(-3.89)\end{array}$ & $\begin{array}{c}-0.0024^{* * *} \\
(-2.56)\end{array}$ & $\begin{array}{c}-0.0046^{* * *} \\
(-3.82)\end{array}$ \\
\hline Bank Health x INSOL & $\begin{array}{l}0.0031 \\
(0.83)\end{array}$ & $\begin{array}{c}0.0076^{\star *} \\
(2.38)\end{array}$ & $\begin{array}{c}-0.0003 \\
(-0.23)\end{array}$ & $\begin{array}{c}0.0068^{\star *} \\
(2.17)\end{array}$ \\
\hline Bank Health x GDP growth & & & & $\begin{array}{c}-0.0004^{\star \star \star} \\
(-2.67)\end{array}$ \\
\hline Bank Health x INSOL x GDP growth & & & & $\begin{array}{c}0.0007^{\star *} \\
(2.04) \\
\end{array}$ \\
\hline $\mathrm{N}$ & 1387620 & 1387620 & 1387620 & 1387620 \\
\hline R-squared & 0.0583 & 0.0583 & 0.0584 & 0.0584 \\
\hline Country-Industry-Year FE & Yes & Yes & Yes & Yes \\
\hline
\end{tabular}

Notes: The dependent variable is a binary indicator of zombie status, based on the IC definition (see Section 4.2.2). All regressions include firm productivity, firm age, and dummies for size. All regressors are lagged by two years. INSOL12 is the aggregate measure without rights of employees, and INSOL13 includes rights of employees. Standard Errors clustered at the country-sector level. t statistics in parentheses. ${ }^{*} p<0.10,{ }^{* *} p<0.05,{ }^{* * *} p<0.01$ 
Table A5. Capital reallocation and bank health: robustness tests

\begin{tabular}{|c|c|c|c|c|}
\hline & $\begin{array}{c}(1) \\
\text { Full Sample } \\
\end{array}$ & $\begin{array}{c}\text { (2) } \\
\text { Manufacturing } \\
\end{array}$ & $\begin{array}{c}\text { (3) } \\
\text { Services }\end{array}$ & $\begin{array}{c}(4) \\
\text { Construction }\end{array}$ \\
\hline \multicolumn{5}{|l|}{ Panel A } \\
\hline TFP & $\begin{array}{c}0.0547^{\star \star \star} \\
(11.63)\end{array}$ & $\begin{array}{c}0.0675^{\star \star \star} \\
(10.90)\end{array}$ & $\begin{array}{c}0.0564^{* * *} \\
(9.77)\end{array}$ & $\begin{array}{c}0.0504^{\star \star \star} \\
(5.87)\end{array}$ \\
\hline TFP $\times$ Bank Health & $\begin{array}{c}0.0165^{\star * *} \\
(5.35) \\
\end{array}$ & $\begin{array}{c}0.0192^{* * *} \\
(3.42)\end{array}$ & $\begin{array}{c}0.0134^{* * *} \\
(3.86) \\
\end{array}$ & $\begin{array}{c}0.0220^{* * *} \\
(3.61)\end{array}$ \\
\hline $\mathrm{R} 2$ & 0.0612 & 0.0709 & 0.0613 & 0.0571 \\
\hline $\mathrm{N}$ & 6063141 & 1080686 & 3678234 & 1304221 \\
\hline \multicolumn{5}{|l|}{ Panel B } \\
\hline lag TFP & $\begin{array}{c}0.0610^{* \star *} \\
(13.20)\end{array}$ & $\begin{array}{c}0.0715^{\star \star *} \\
(8.06)\end{array}$ & $\begin{array}{c}0.0590^{* * *} \\
(11.61)\end{array}$ & $\begin{array}{c}0.0649^{\star \star *} \\
(5.97)\end{array}$ \\
\hline TFP $\times$ Crisis & $\begin{array}{c}-0.0115^{\star *} \\
(-2.58)\end{array}$ & $\begin{array}{l}-0.0058 \\
(-0.72)\end{array}$ & $\begin{array}{l}-0.0045 \\
(-0.69)\end{array}$ & $\begin{array}{l}-0.0262^{* * *} \\
(-3.08)\end{array}$ \\
\hline $\mathrm{R} 2$ & 0.0606 & 0.0705 & 0.0609 & 0.0562 \\
\hline $\mathrm{N}$ & 6063141 & 1080686 & 3678234 & 1304221 \\
\hline \multicolumn{5}{|l|}{ Panel C } \\
\hline$\overline{T F P}$ & $\begin{array}{l}0.0516^{\star \star \star} \\
(9.40)\end{array}$ & $\begin{array}{c}0.0672^{\star \star \star} \\
(4.89)\end{array}$ & $\begin{array}{c}0.0502^{* * *} \\
(8.17)\end{array}$ & $\begin{array}{c}0.0536^{* * *} \\
(4.20)\end{array}$ \\
\hline TFP x Bank Health & $\begin{array}{c}0.0203^{\star \star \star} \\
(3.60)\end{array}$ & $\begin{array}{c}0.0098 \\
(0.63)\end{array}$ & $\begin{array}{c}0.0194^{* * *} \\
(3.07)\end{array}$ & $\begin{array}{c}0.0228^{*} \\
(1.90)\end{array}$ \\
\hline TFP $\times$ Crisis & $\begin{array}{c}0.0047 \\
(0.75)\end{array}$ & $\begin{array}{c}0.0075 \\
(0.53)\end{array}$ & $\begin{array}{c}0.0108 \\
(1.28)\end{array}$ & $\begin{array}{r}-0.0083 \\
(-0.73)\end{array}$ \\
\hline TFP $\times$ Bank Health $x$ Crisis & $\begin{array}{l}-0.0035 \\
(-0.48) \\
\end{array}$ & $\begin{array}{c}0.0185 \\
(1.15) \\
\end{array}$ & $\begin{array}{l}-0.0041 \\
(-0.47)\end{array}$ & $\begin{array}{l}-0.0052 \\
(-0.38) \\
\end{array}$ \\
\hline $\mathrm{N}$ & 6063141 & 1080686 & 3678234 & 1304221 \\
\hline $\mathrm{R} 2$ & 0.0612 & 0.071 & 0.0613 & 0.0573 \\
\hline Country-Industry-Year FE & Yes & Yes & Yes & Yes \\
\hline
\end{tabular}

Notes: The dependent variable is log real capital growth. All regressions include lagged firm age and dummies for size. Standard Errors clustered at the country-sector level. $t$ statistics in parentheses.

${ }^{*} p<0.10,{ }^{* *} p<0.05,{ }^{* * *} p<0.01$ 
Figure A1. The evolution of bank health
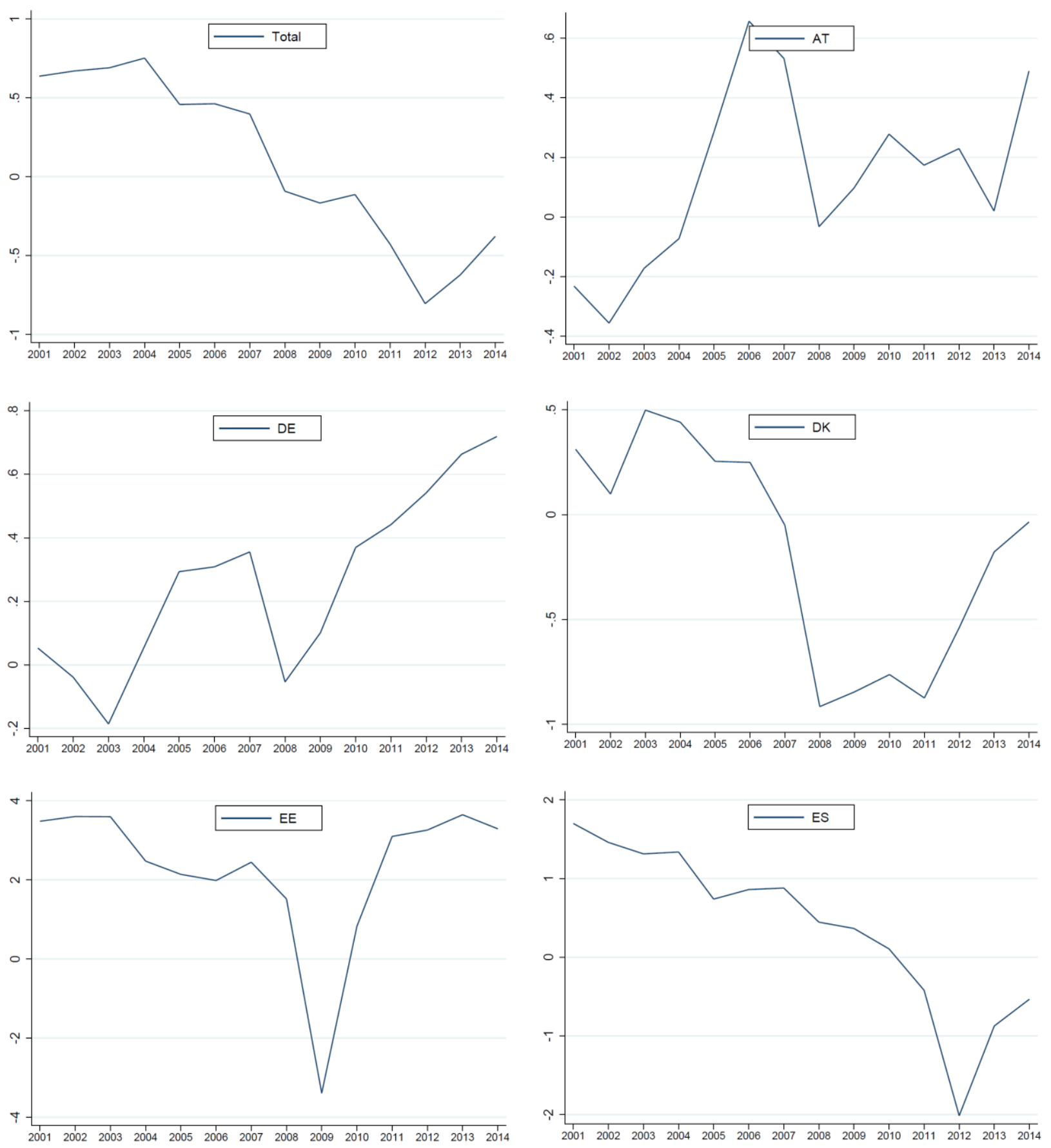
ECO/WKP(2017)65
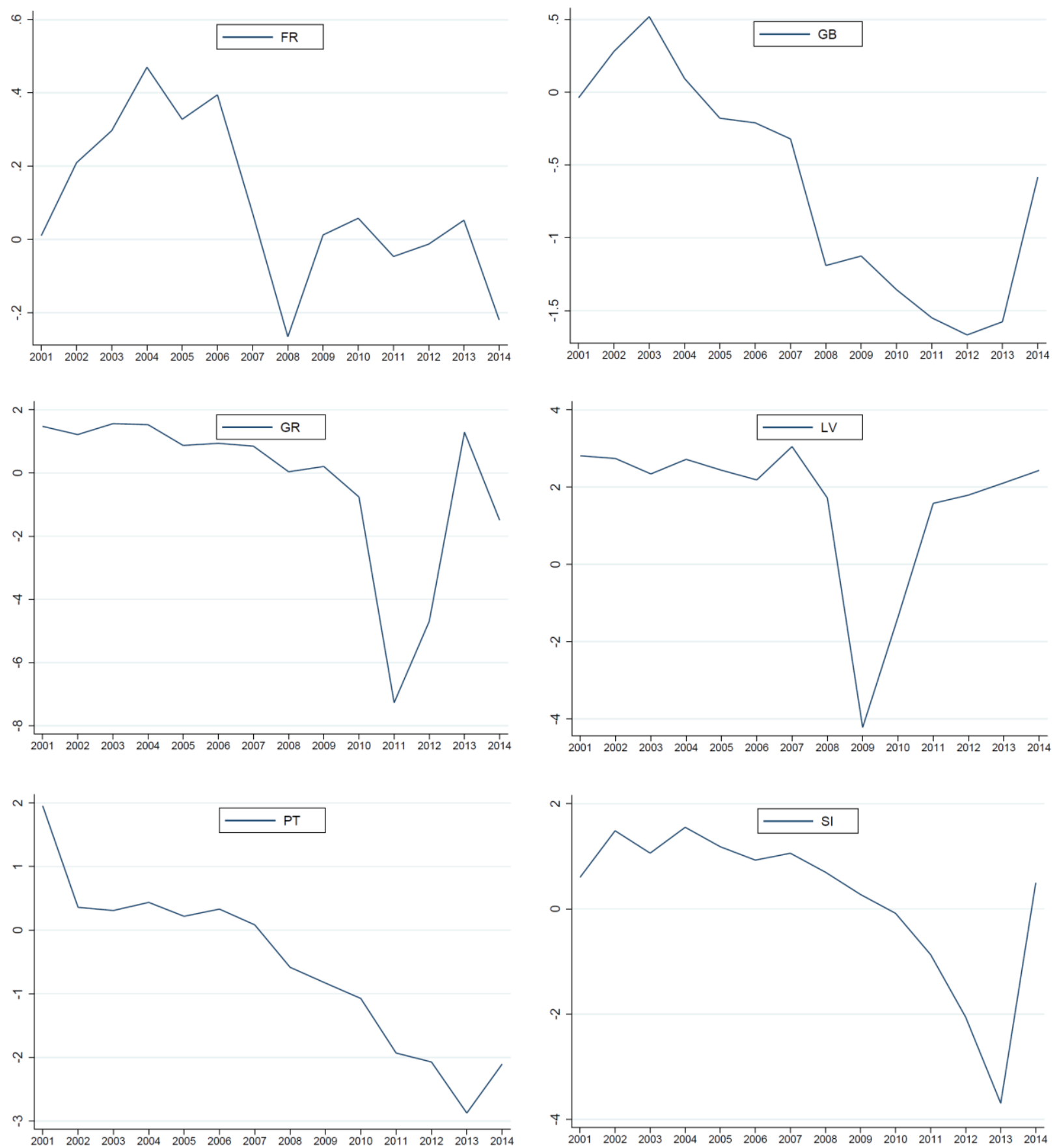

Notes: The chart gives average bank health for banks in our dataset (11 countries), weighted by the number of firms for which a bank is considered to be their main bank. Bank health is given by the first principal component (i.e. the one associated with the largest eigenvalue) from a principal component analysis of seven core balance sheet and financial statement variables of banks. These are tangible common equity, net income, net interest income, NPLs, Z-score (a measure of riskiness of assets), return on average assets, and retail funding, all as a share of total assets. 
Figure A2. Zombie firms and weak banks: additional evidence
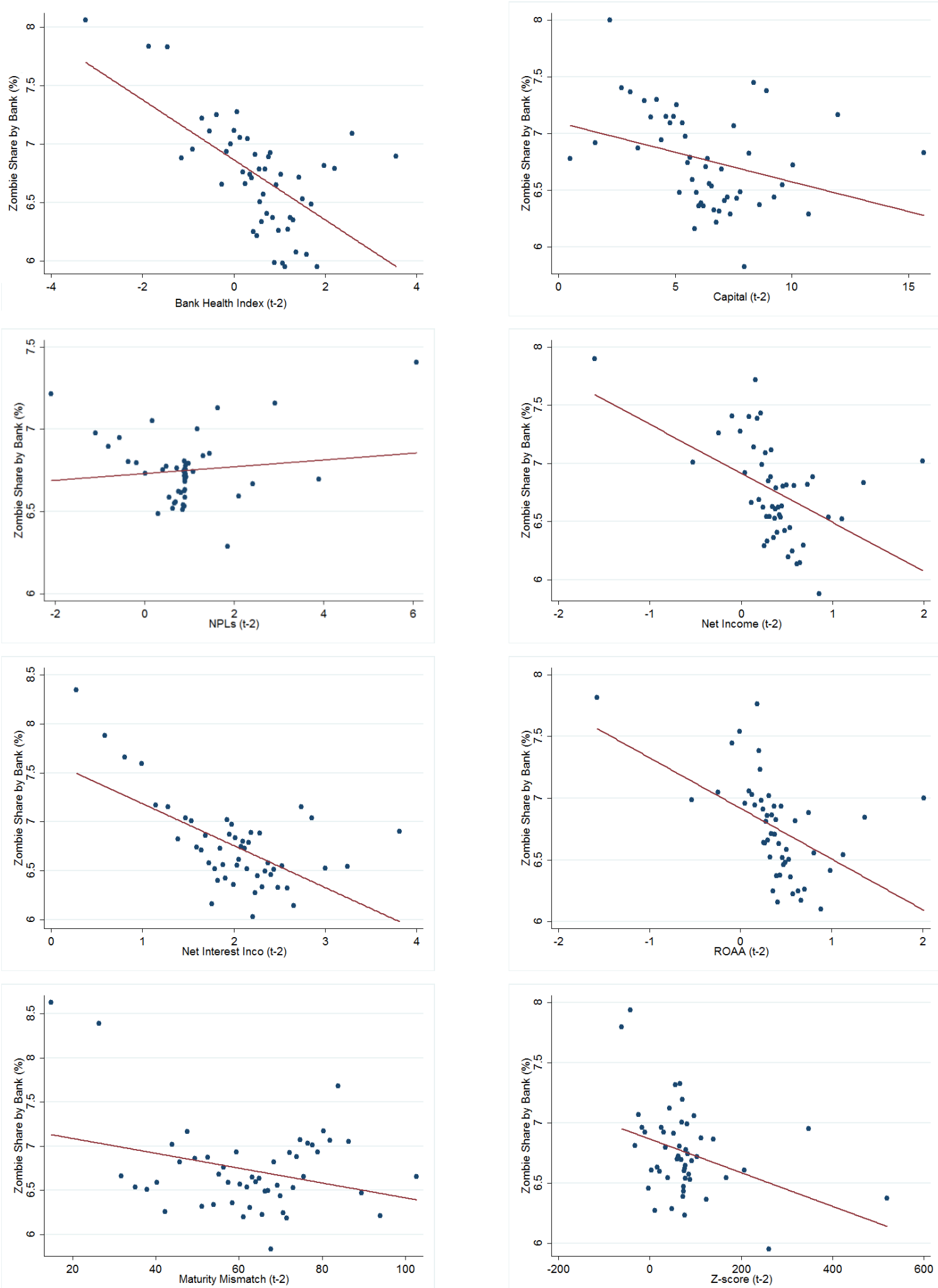